\title{
STRATEGI KOMUNIKASI PEMASARAN MULTILEVEL MARKETING ORIFLAME TERHADAP KEPERCAYAAN DISTRIBUTOR SEBAGAI MITRA USAHA
}

\section{STRATEGY MAREKETING OF COMMUNICATION OF MULTILEVEL MARKETING ORIFLAME WITH CONFIDENCE DISTRIBUTOR AS BUSINESS PARTNERS}

\author{
R Rohanaํ, Agustini2a, IA Ratnamulyani³ \\ ${ }^{1}$ Alumni Ps. Ilmu Komunikasi, Fakultas Ilmu Sosial dan Ilmu Politik, Universitas Djuanda Bogor, ${ }^{2}$ Dosen \\ Pembimbing I Program Studi Komunikasi, Fakultas Ilmu Sosial dan Ilmu Politik, ${ }^{3}$ Dosen Pembimbing II \\ Program Studi Komunikasi Universitas Djuanda Bogor, Jl. Tol Ciawi No.1 Kotak Pos 35 Bogor 16720 \\ a Korespondensi: Agustini, Email: agutsini@unida.ac.id
}

(Diterima: 08-06-2015; Ditelaah: 20-07-2015; Disetujui: 17-08-2015)

\begin{abstract}
Oriflame cosmetics is a multilevel marketing company that survived long enough in Indonesia, which is about 20 years. But the increasing number of multilevel marketing company that spreads its wings in the field of cosmetics, the competitor will be growing Oriflame. Oriflame offers some ways to still give credence to any distributor, it is this which makes the Oriflame business to be so unique. The purpose of this study was to analyze the effect of marketing multilevel marketing communications strategy of the trust Oriflame distributors as business partners in Taman Topi Square Bogor. This study describes the marketing communication strategies undertaken by Oriflame through a network of distributors for product marketing success. This research is a descriptive correlational research with quantitative approach. This study focuses on Oriflame marketing communications strategy which is spearheading the creation of quality business partners confidence. Data collected through observation, interviews and distributing questionnaires to the respondents. These results indicate that the multilevel marketing marketing communication strategies influence the confidence Oriflame distributors as business partners with a moderate level of influence that the correlation of $26.32 \%$.
\end{abstract}

Keywords: Strategy, Marketing Communication, Confidence Distributor, Oriflame MLM.

\begin{abstract}
ABSTRAK
Oriflame merupakan perusahaan multilevel marketing kosmetik yang bertahan cukup lama di Indonesia, yaitu sekitar 20 tahun. Tetapi semakin banyaknya perusahaan multilevel marketing yang mengembangkan sayapnya pada bidang kosmetik, maka pesaing Oriflame akan semakin bertambah. Oriflame menawarkan beberapa cara untuk tetap memberikan kepercayaan kepada setiap distributornya, hal inilah yang membuat bisnis Oriflame menjadi begitu unik. Tujuan penelitian ini adalah untuk menganalisis pengaruh strategi komunikasi pemasaran multilevel marketing Oriflame terhadap kepercayaan distributor sebagai mitra usaha di Taman Topi Square Bogor. Penelitian ini mendeskripsikan tentang strategi komunikasi pemasaran yang dilakukan oleh Oriflame melalui jaringan distributor untuk keberhasilan pemasaran produk. Jenis penelitian ini adalah penelitian Deskriptif Korelasional dengan pendekatan Kuantitatif. Penelitian ini berfokus pada strategi komunikasi pemasaran Oriflame yang merupakan ujung tombak terciptanya kualitas kepercayaan mitra usaha. Pengumpulan data dilakukan melalui observasi, wawancara dan menyebarkan kuesioner kepada responden. Hasil penelitian ini menunjukan bahwa strategi komunikasi pemasaran multilevel marketing Oriflame berpengaruh terhadap kepercayaan distributor sebagai mitra usaha dengan tingkat pengaruh sedang yang korelasinya sebesar $26,32 \%$.
\end{abstract}

Kata Kunci : Strategi, Komunikasi Pemasaran, Kepercayaan Distributor, MLM Oriflame. 
R Rohana, Agustini, IA Ratnamulyani. 2015. Strategi Komunikasi Pemasaran Multilevel Marketing Oriflame Terhadap Kepercayaan Distributor Sebagai Mitra Usaha Di Taman Topi Square Bogor. Jurnal Komunikatio 1(2): 73-98. 


\section{PENDAHULUAN}

Persaingan dunia bisnis sudah semakin luar biasa. Untuk mendapatkan pelanggan baru dan mempertahankan pelanggan, perusahaan menghabiskan banyak uang untuk melakukan kegiatan promosi. Tujuannya agar pelanggan mau membeli produk/jasa yang ditawarkan. Oriflame merupakan perusahaan Multilevel Marketing kosmetik yang bertahan cukup lama di Indonesia, yaitu sekitar dua puluh tahun. Sebelumnya, Oriflame memiliki pesaing kuat dalam bidang pemasaran jaringan, yaitu perusahaan Avon, yang akhirnya sekarang perusahaan Avon tersebut gulung tikar. Meski produk kosmetik Avon memiliki kualitas bagus, namun harganya relatif murah sehingga tingkat keuntungan yang diperoleh kecil. Apalagi pemasarannya menggunakan sistem direct selling yang seharusnya harganya bisa lebih tinggi. Kini Avon tidak lagi beredar di pasar. Pihak Avon Indonesia menjelaskan, keputusan itu ditetapkan melalui Rapat Umum Pemegang Saham Luar Biasa. Dari penelusuran info APLI, penutupan Avon memang disebabkan oleh faktor-faktor yang sifatnya sangat basic atau mendasar, selain ada faktor pasar yang mempengaruhi. Semakin besar perkembangan Avon, semakin banyak pula cabang yang harus didirikan sehingga semakin besar juga biaya operasionalnya. Manajer Avon kurang mempertimbangkan keuntungan yang diperoleh sehingga ia terlalu fokus terhadap satu tujuan (produk laku dipasaran) namun tidak memperhatikan dan mempertimbangkan biaya yang dikeluarkan untuk membiayai karyawan. Sehingga keuntungan perusahaan Avon kian menipis dan akhirnya menyebabkan kebangkrutan perusahaan Avon.

Adapun kesalahan-kesalahan umum yang dapat menurunkan kepercayaan distributor sebagai mitra usahanya yaitu: Sistem pemberian reward yang sama kepada setiap karyawan adalah sebuah kesalahan, dalam pemberian reward seharusnya sesuai dengan kinerja yang dilakukan karyawan. Prinsip ini akan memberikan kesempatan bagi semua karyawan yang ada untuk bekerja lebih giat guna memperoleh reward yang disediakan perusahaan. Selain itu, membuat pekerjaan tampak berat akan membuat kinerja dan kepercayaan distributor sebagai mitra usaha menurun dan akan mempengaruhi distributor yang lain untuk ikut bermalas-malasan. Lalu adapula Downsizing atau penciutan organisasi karena tampaknya inilah cara paling cepat untuk menaikkan laba perusahaan dengan demikian manajer akan mendapatkan bonus lebih besar, padahal riset menunjukkan bahwa dalam jangka panjang, perusahaan yang melakukan downsizing justru lebih sulit mendapatkan profit. Juga menumpuk-numpuk kekuasaan yang biasanya hanya sebagian orang yang mendominasi kekuasaan yang tidak memberikan kesempatan kepada orang lain berkembang dan berkuasa dibidangnya. Dan tidak banyak melakukan pelatihan dan pengembangan SDM.

Berbeda dengan Oriflame yang dapat dianggap sebagai pemimpin pasar dalam perusahaan jaringan yang bergerak dalam bidang kosmetik. Oriflame menawarkan tiga cara untuk menghasilkan uang yaitu menghemat dari pembelian atas produk-produk Oriflame dengan menjadi Consultant Oriflame kita bisa berhemat dalam membeli produk dengan sedikitnya diskon $23 \%$, menunjukkan katalog dan mengumpulkan diskon atas penjualan dan mengajak orang-orang bergabung dan membangun sebuah tim untuk menghasilkan uang bersama-sama akan mendapat komisi $21 \%$ atas penjualan tim hal inilah yang membuat bisnis Oriflame menjadi begitu unik. Oriflame merupakan salah satu perusahaan Multilevel Marketing yang terdaftar pada APLI dengan nama perusahaan di Indonesia yaitu PT Orindo Alam Ayu, bergerak pada bidang kosmetik yang memproduksi berbagai produk kosmetik untuk perawatan tubuh maupun kecantikan. Produk yang dipersembahkan Oriflame antara lain adalah toiletries, perawatan kulit, tata rias, wewangian, dan perawatan untuk anak-anak.

Selain itu Oriflame juga memasarkan produknya dengan cara jaringan penjualan mandiri (independent sales force). Oriflame adalah perusahaan direct selling yang bergantung pada distributor yang berperan sebagai tenaga penjual dimana merupakan ujung tombak perusahaan dalam memasarkan dan menjual produknya. Personal selling didukung oleh peran tenaga penjual dan peran tersebut sangat penting dalam peningkatan volume penjualan Oriflame. Sistem ini dimudahkan bagi siapapun yang berkecimpung dalam berbisnis jaringan atau Multilevel Marketing, apalagi bila perusahaan tersebut memiliki produk yang dibutuhkan orang banyak dan tidak sulit untuk mendapatkannya dengan cara yang lebih nyaman yaitu 
memanfaatkan teknologi untuk mempercepat kesuksesannya.

Menjadi distributor oriflame berarti memiliki penghasilan tak terbatas dan peluang karir yang luar biasa, pengembangan pribadi dan rasa saling memiliki dalam komunitas persahabatan global. Memanfaatkan kegiatan personal selling dengan melakukan pendekatan-pendekatan yaitu presentasi dan demonstrasi produk serta kesaksian tentang manfaat produk sehingga diharapkan konsumen akan tertarik dan akhirnya membeli produk tersebut tanpa berpikir panjang.

Distributor ini ternyata tidak hanya cocok untuk kalangan ibu saja, para suami pun bisa menjalankan usaha bisnis ini untuk menambah penghasilan utama. Peluang usaha ini juga cocok dikerjakan oleh semua kalangan, ibu rumah tangga, mahasiswa, remaja baik muda maupun tua, pria maupun wanita. Karena bisnis ini adalah bisnis rumahan yang bisa kapan dan dimana saja dikerjakan. Memang diakui bahwa $80 \%$ dari produk oriflame ditujukan untuk kaum perempuan akan tetapi bukan berarti tidak ada produk yang bisa digunakan oleh kaum pria dan anak-anak.

Saat ini oriflame juga mempunyai beberapa produk untuk pria misalnya parfume, shampoo, sabun, deodorant. Tersedia juga aneka produk untuk anak-anak dan bayi yang cukup lengkap. Oleh karena itu, semua kalangan bisa menjalankan usaha bisnis ini, tak hanya kaum perempuan saja. Tugas utama dalam menjalankan peluang bisnis ini adalah merekrut untuk membangun kerajaan bisnis yang berfungsi sebagai mesin uang. Ada banyak keuntungan yang bisa didapatkan dengan menjalankan usaha bisnis oriflame diantaranya adalah bonus bulanan, Cash Award pada pencapaian level tertentu, berbagai pelatihan gratis seputar kesehatan, kecantikan, dan sebagainya tanpa dipungut biaya sedikitpun, bebas resiko penipuan karena semua sistem yang dijalankan dalam bisnis ini cukup jelas dan sangat menjanjikan terutama bagi mereka yang serius untuk merekrut anggota sebanyakbanyaknya.

Dengan adanya hubungan terhadap orang lain akan mendatangkan keuntungan karena adanya kerjasama diantara kedua belah pihak, selain itu dapat juga sebagai sarana penunjang kegiatan usaha. Pengusaha dalam hal ini tidak akan bisa bergerak sendiri, mereka harus membina hubungan dengan orang lain setidaknya kepada pelanggan, tanpa adanya hubungan ini seorang pengusaha atau consultan tidak akan mampu maju dan mengembangkan usahanya. Rasa malas dan kejenuhan dari anggota jaringannya untuk bagaimana mengembangkan usahanya akan menghambat satu jaringan bisnis tersebut, pengusaha dalam hal ini Leader mengembangkan strategi-strategi yang kemudian akan dipergunakan dalam jaringan tersebut.

Persaingan antar perusahaan kosmetik bertambah ketat, sementara tantangantantangan eksternal juga bertambah banyak mengingat semakin dinamis nya situasi ekonomi nasional saat ini. Maka Oriflame pun melakukan strategi untuk meningkatkan kepercayaan distributor sebagai mitra usaha adalah produk yang berkualitas diantaranya dibuat dari bahan alami tumbuh-tumbuhan, produk halal dan aman dikonsumsi oleh kaum muslim, sehat bagi semua jenis kulit, oriflame memenuhi semua kebutuhan dari kecantikan sampai kesehatan, kemasan produk dapat didaur ulang dan meminimalisir limbah pabrik dan diformulasikan sesuai dengan standar industri tinggi dan pedoman etika. Adapun strategi oriflame lainnya adalah penetapan harga yang dapat menjangkau kantong pelajar, dan dengan membayar harga yang murah akan mendapatkan kualitas produk yang baik. Demikian hal nya dengan promosi oriflame yang gencar dilakukan baik langsung maupun media online dan dapat menjadi sarana untuk bertukar pikiran antar distributor dalam memperluas jaringan.

Marketing merupakan sarana promosi massal yang dilakukan dengan menjalin hubungan dengan konsumen perusahaan dan masyarakat umum dengan tujuan untuk membangun citra perusahaan yang positif agar mendapat publisitas ynag luas, dan mengatasi kabar angin, laporan, serta kejadian-kejadian yang tidak sesuai dengan kenyataan.

Peran marketing oriflame bertugas untuk mengurus komunikasi internal dalam perusahaan, dan memastikan setiap karyawan mendapat informasi yang sama, terutama menyangkut perusahaan oriflame dan yang berhubungan dengan brand image Oriflame, juga komunikasi ekternal dengan para konsultan oriflame dan para media. Marketing harus memiliki keterampilan dalam promosi produk dan mengetahui produk yang dibutuhkan konsumen. Tugas marketing secara lebih rinci adalah membentuk persepsi atau 
opini mengenai brand oriflame via komunikasi baik internal dan eksternal, sperti press conference mengenai produk baru oriflame. Lalu mengurus advertising atau iklan di media, Brand Positoning dan Brand Awwereness mengenai oriflame.

Marketing mempunyai tugas yakni dalam satu tahun ada visi kedepan yang ingin dicapai mengenai brand image perusahaan oriflame dan membuat strategi dan konsep secara keseluruhan apa yang ingin dicapai departemen pemasaran atau marketing departement dalam satu tahun ini.

\section{Rumusan Masalah}

Berdasarkan latar belakang yang telah dipaparkan diatas muncul permasalahan yang dapat dirumuskan masalah sebagai berikut :

1. Bagaimana strategi komunikasi pemasaran multilevel marketing oriflame di Taman Topi Square ?

2. Hal apa yang meyakinkan kepercayaan distributor sebagai mitra usaha pada oriflame?

3. Bagaimana pengaruh strategi komunikasi pemasaran multilevel marketing oriflame terhadap kepercayaan distributor sebagai mitra usaha?

\section{Tujuan Penelitian}

1. Untuk menganalisis strategi komunikasi pemasaran multilevel marketing oriflame di Taman Topi Square.

2. Untuk menganalisis kepercayaan dalam hal apa saja yang meyakinkan distributor sebagai mitra usaha pada oriflame.

3. Untuk menganalisis pengaruh strategi komunikasi pemasaran multilevel marketing oriflame terhadap kepercayaan distributor sebagai mitra usaha.

\section{Manfaat Penelitian}

Manfaat penelitian ini meliputi kegunaan teoritis dan kegunaan praktis, sebagai berikut :

1. Kegunaan Teoritis

Penelitian ini diharapkan dapat dijadikan bahan masukan terhadap pengembangan ilmu pengetahuan dan teknologi khususnya ilmu komunikasi sehingga dapat memberikan manfaat sebagai sumbangan Karya Ilmiah terhadap mahasiswa komunikasi. Selain itu, sebagai bahan referensi bagi peneliti selanjutnya, khususnya yang mengadakan penelitian dengan objek yang sama.

2. Kegunaan Praktis

Diharapkan menjadi bahan
masukan dan informasi bagi perusahaan yang bersangkutan dalam melakukan jaringan komunikasi pemasaran. Juga sebagai bahan perbandingan dalam memperbaiki sistem strategi komunikasi pemasaran perusahaan oriflame melalui jaringan distributor untuk keberhasilan pemasaran produk.

\section{TINJAUAN TEORI}

\section{Komunikasi Pemasaran}

Menurut Wikipedia Bahasa Indonesia, komunikasi pemasaran (marketing communication) adalah sarana dimana perusahaan berusaha menginformasikan, membujuk, dan mengingatkan konsumen secara langsung maupun tidak langsung tentang produk dan merek yang dijual. Komunikasi pemasaran mempresentasikan "suara" perusahaan dan mereknya serta merupakan sarana dimana perusahaan dapat membuat dialog dan membangun hubungan dengan konsumen. Komunikasi pemasaran bagi konsumen, dapat memberitahu atau memperlihatkan kepada konsumen tentang bagaimana dan mengapa suatu produk digunakan, oleh orang macam apa, serta dimana dan kapan.

Menurut Prisgonanto, (2006) komunikasi pemasaran adalah sarana penting dalam mengenali diri dan kemampuan perusahaan, baik secara internal maupun eksternal. Kemampuan mengenali kondisi pasar, pelanggan, dan internal organisasi perusahaan sebagai modal utama dalam pengembangan serta perluasan jangkauan pasar dan pemasaran yang ada. Komunikasi pemasaran berkontribusi pada ekuitas merek dengan menanamkan merek dalam ingatan dan menciptakan citra merek serta mendorong penjual dan bahkan mempengaruhi nilai pemegang saham. Komunikasi pemasaran 
merupakan aspek penting dalam misi pemasaran serta penentu suksesnya suatu pemasaran.

Komunikasi pemasaran sebagai kegiatan komunikasi pemasaran dengan menggunakan teknik-teknik komunikasi yang ditujukan untuk memberikan informasi kepada orang banyak dengan harapan agar tujuan perusahaan tercapai, yaitu terjadinya peningkatan pendapat sebagai hasil penambahan penggunaan jasa atau pembelian produk yang ditawarkan. Komunikasi pemasaran adalah bentuk komunikasi yang ditujukan untuk memperkuat strategi pemasaran, guna meraih segmentasi yang lebih luas. Kajian ini dapat dikatakan juga sebagai jumlah upaya untuk memperkuat loyalitas pelanggan terhadap produk, yaitu barang dan jasa yang dimiliki perusahaan (Soemanagara,2006).

Adapun dua unsur pokok dalam komunikasi pemasaran, yaitu :

1. Komunikasi : proses dimana pemikiran dan pemahaman disampaikan antar individu, atau antar organisasi dengan individu. Komunikasi sebagai proses penyampaian pesan yang merupakan gagasan atau informasi pengirim melalui suatu media kepada penerima agar mampu memahami maksud pengirim.

2. Pemasaran : sekumpulan kegiatan dimana perusahaan atau organisasi lainnya mentransfer nilai-nilai (pertukaran) tentang informasi produk, jasa, dan ide antara mereka dengan pelanggannya.

Dalam buku Komunikasi Pemasaran, Agus Hermawan, (2012). Hubungan strategi dan pemasaran menjadi penting dalam dunia bisnis, karena pada hakikatnya hubungan ini merupakan langkah-langkah kreatif yang berkesinambungan yang diupayakan oleh sebuah perusahaan guna mencapai target pemasaran terbaik dalam rangka mewujudkan kepuasan konsumen secara maksimal. Strategi pemasaran sangat diperlukan untuk mencegah penurunan jumlah konsumen serta jatuhnya daya saing produk bisnis di pasar. Tanpa sadanya strategi pemasaran yang teruji, bisa dipastikan pemasaran akan jatuh, terlebih apabila muncul berbagai produk kompetitif yang dikeluarkan oleh rival-rival bisnis. Melalui strategi ini sebuah proses pemasaran yang baik dapat dipertahankan, memberikan cara-cara yang baru yang membuat para pelanggan senantiasa menemukan keunikan dalam produk, hal ini merupakan salah satu strategi yang dibutuhkan dalam pemasaran.

Maka dapat disimpulkan, strategi komunikasi pemasaran adalah pengukuran dalam arti tercapainya sasaran atau tujuan yang telah ditentukan dalam menyampaikan pemahaman atau informasi mengenai produk, jasa, dan ide dengan pelanggannya

Berdasarkan definisi tersebut hal-hal yang perlu diperhatikan untuk pemasaran yaitu : Product (produk), Price (harga), Place (tempat, termasuk juga distribusi), Promotion (promosi).

\section{Produk (product) Oriflame}

Menurut Mahmud Mahfoedz, (2010) dalam buku Komunikasi Pemasaran Modern, Produk adalah objek yang sangat vital yang mempengaruhi keberhasilan perusahaan dalam mendatangkan tingkat keuntungan atau laba yang akan tetap menjaga aktivitas operasional dan kesehatan keuangan perusahaan. Suatu produk bukan sekedar komponen fisik, melainkan barang atau jajsa yang mencerminkan potensi untuk memenuhi rentang kebutuhan konsumen, baik yang disadari maupun yang tidak disadari.

Menurut Wikipedia, Secara luas produk adalah segala sesuatu yang dapat ditawarkan ke pasar untuk memuaskan suatu kebutuhan atau keinginan. Melalui produk, produsen dapat memanjakan konsumen. Karena dari produk akan dapat diketahui, seberapa besar kepuasan dan kebutuhan akan produk itu sendiri dalam kehidupan konsumen.

Oriflame adalah kosmetika berkualitas berbahan dasar alami dari Swedia. Berdasarkan Peraturan Kepala Badan Pengawas Obat dan Makanan Republik Indonesia Nomor HK.00.05.1.23.3516 tentang "Izin Edar Produk Obat, Obat Tradisional, Kosmetik, Suplemen Makanan dan Makanan yang Bersumber, Mengandung dari Bahan Tertentu dan atau Mengandung Alkohol" tertanggal 31 Agustus 2009, semua produk oriflame yang beredar di market Indonesia sudah memenuhi persyaratan peraturan ini. Jadi, produk oriflame dapat dipastikan aman dan halal. Beberapa kandungan bahan kosmetik oriflame antaranya blueberry, horse chesnut, yarrow, bunga iris, kelapa, birch, cloudberry, apel dan lain sebagainya yang 
dikemas unik hingga dapat menarik perhatian konsumen.

\section{Kualitas Produk}

Menurut Mahfoedz, (2010) Kualitas merupakan salah satu sarana positioning penting bagi pemasar atau perusahaan. Dalam pengembangan suatu produk, terlebih dahulu pemasar harus memilih tingkat kualitas yang akan mendukung posisi produk di pasar sasaran. Dalam hal ini, kualitas produk berarti kemampuan suatu produk untuk melakukan fungsinya, yang meliputi daya tahan, keandalan, presisi, kemudahan penggunaan, dan perbaikan, serta ciri-ciri lain yang menunjukan nilainya. Meskipun beberapa ciri tersebut dapat diukur secara objektif, dari sudut pandang pemasaran, kualitas harus diukur menurut persyaratan persepsi konsumen.

Kualitas produk oriflame terlihat dari bahanbahannya yang terbuat alami dari tumbuhtumbuhan dan tanpa bahan kimia yang aman untuk semua jenis kulit dan halal digunakan oleh kaum muslim.

\section{Ciri Produk}

Menurut Mahfoedz (2010) dalam buku Komunikasi Pemasaran Modern. Suatu produk dapat ditawarkan dengan berbagai ciri dan karakteristik. Model sederhana tanpa variasi merupakan titik permulaan. Perusahaan dapat menciptakan model yang lebih menarik dengan penambahan beberapa karakteristik. Karakteristik merupakan sarana kompetitif untuk membedakan produk sebuah perusahaan dari produk buatan perusahaan lainnya yang menjadi pesaing.

Ciri produk oriflame adalah dapat memenuhi semua kebutuhan dari kecantikan seperti makeup (lipstick, eyeliner, mascara, blushon, eyeshadow dll), sampai kesehatan seperti nutrishake (suplemen untuk menurunkan berat badan).

\section{Desain Produk}

Menurut Mahmud Mahfoedz, (2010) Cara lain untuk menjadikan suatu produk tampak lebih menarik dapat dilakukan melalui desain. Desain merupakan konsep yang lebih penting daripada bentuk. Bentuk semata mengungkapkan sifat fisik produk yang dapat dilihat. Bentuk yang mengagumkan dapat menarik perhatian, tapi ini tidak menjadikan produk berfungsi lebih baik. Desain yang baik memberi nilai tambah pada manfaat produk, menjadikannya enak dipandang dan nyaman digunakan.

Desain produk oriflame termasuk unik dengan memproduksi berbagai parfum yang bentuknya beraneka ragam yang dapat menarik minat konsumen selain aroma nya segar dan tahan lama.

\section{Harga (price) Oriflame}

Penetapan harga dari suatu produk juga menjadi hal yang sangat penting. Penetapan harga dari suatu produk akan sangat mempengaruhi keberhasilan perusahaan untuk memperoleh keuntungan. Penetapan harga dari suatu produk akan sangat dipengaruhi dari seberapa pengorbanan yang telah dilakukan dalam memproduksi produk itu sendiri. Semakin besar pengorbanan yang dilakukan maka akan semakin besar dan tinggi harga yang ditetapkan oleh produk itu.

Menurut Mahmud Mahfoedz, (2010) Harga sangat mempengaruhi penjualan suatu produk yang ditawarkan perusahaan. Penetapan harga membutuhkan strategi pemasaran yang matang agar perusahaan tidak mengalami kerugian. Menetapkan harga yang murah belum tentu menjadi solusi yang tepat, yang diperlukan adalah penetapan harga ynag cerdas sehingga dapat membantu meningkatkan penjualan. Strategi dalam menetapkan harga produk dapat dilakukan dengan menganalisis keunggulan dan kekurangan dari produk yang dimiliki. Dengan jalan ini maka kelak di kemudian hari tidak akan terdengar kabar bahwa harga produk perusahaan terlalu mahal atau terlalu murah dan tidak sesuai dengan kualitas yang dimilikinya.

Harga produk oriflame sangat sesuai dengan kualitas produk yang ditawarkan. Selain terjangkau, harga oriflame kompetitif dan selalu memberikan potongan harga/diskon yang berbeda setiap bulannya.

\section{Tempat (place) Oriflame}

Tempat pendistribusian juga merupakan bagian vital dari bagian strategi pemasaran. Pemilihan strategi dengan tepat akan dapat membantu produk sampai ke konsumen sesuai 
dengan harga yang telah dutentukan perusahaan. Mahmud Mahfoedz, (2010).

SPO adalah Servis Point Oriflame, sarana yang berguna untuk mempermudah distributor untuk melakukan order dari daerah manapun agar produk pesanan bisa segera sampai ke konsumen.

\section{Promosi (promotion) Oriflame}

Kegiatan promosi biasanya merupakan salah satu komponen yang menjadi prioritas dari kegiatan pemasaran. Dengan adanya promosi maka konsumen akan mengetahui bahwa perusahaan meluncurkan produk baru yang akan menggoda konsumen untuk melakukan kegiatan pembelian. Banyak yang mengatakan bahwa kegiatan promosi identik dengan dana yang dimiliki oleh perusahaan. Menurut Mahmud Mahfoedz, (2010) Semakin besar dana yang dimiliki oleh suatu perusahaan umumnya akan menghasilkan promosi yang juga sangat gencar. Namun dana bukanlah segala-galanya. Dana yang terbatas dapat diatasi dengan inovasi yang lebih cerdas dan tepat.

Menurut buku "Inilah Oriflame The Opportunity Presentation" ada beberapa cara/strategi jitu Oriflame untuk menarik mitra usaha yaitu distributor Oriflame adalah sebagai berikut :

\section{Event Manager}

Event manager akan berusaha merancang activity selama satu tahun, event dan langkah apa yang dilakukan guna mencapai visi marketing department itu dalam satu tahun baik itu gathering antar distributor atau yang lain sebagainya. Lalu marketing admin akan membantu event Manager dalam hal operasionalnya dan logistiknya. Lalu bagian online akan berusaha mensupport atau mendukung langkah yang akan dilakukan untuk mencapai visi selama 1 tahun itu lewat sistem online, website, facebook, twitter, dan media sosial online lainnya. Marketing departement juga bertugas atau mempunyai tugas tahunan yakni merancang atau membuat event lainya, departemen pemasaran bekerjasama dengan departemen lainnya.

Dalam hal komunikasi internal perusahaan, departemen pemasaran bertugas memberikan informasi lewat newsletter ynag dikeluarkan tiap bulannya, newsletter itu memuat produkproduk terbaru oriflame beserta kandungan serta manfaatnya dan menginformasikan event yang telah dilakukan, pencapaian yang telah dicapai oleh karyawan, sistem kerja oriflame dan berita terkait lainnya yang perlu diketahui oleh bagian internal perusahaan. Programprogram tanggung jawab perusahaan juga selalu di muat dalam newsletter oriflame.

\section{Catalouge Team}

Catalogue team akan berusaha menterjemahkan visi yang diinginkan marketing director lewat katalog-katalog oriflame setiap bulannya agar bersifat persuasif bagi setiap pembacanya agar tertarik dan membeli produk tersebut.

3. Iklan

Iklan (Tjiptono,2008) merupakan sebuah bentuk komunikasi tidak langsung, yang didasari pada informasi tentang keunggulan atau keuntungan suatu produk, yang disusun sedemikian rupa sehingga menimbulkan rasa menyenangkan yang akan mengubah pikiran seseorang untuk melakukan pembelian. Oriflame merupakan sebuah perusahaan multi level marketing ynag dijalankan oleh seorang konsultan independen. Oleh karena itu , tidak hanya perusahaan yang membuat iklan akan tetapi konsultan juga melakukan kegiatan periklanan. Namun bedanya, jika pihak perusahaan mengiklankan produk atau corporate, konsultan independen melakukan iklan untuk memperkenalkan dirinya pribadi, yang menguntungkan dirinya. Karena konsultan disini dituntut untuk merekrut jaringan yang banyak sehingga konsultan tersebut bisa mendapatkan keuntungan yang berlimpah atau banyak pula. Oleh karena itu, iklannya pun kadangkala juga tentang jaringan dimana dia bernaung.

Ada banyak hal yang dilakukan oleh konsultan independen ketika melakukan kegiatan periklanan. Mulai dari membuat iklan cetak maupun iklan online. Iklan cetak ini berupa iklan koran, ataupun melalui brosur. Sedangkan iklan online bisa berupa iklan berbayar ataupun iklan gratis yang banyak sekali ditawarkan di internet. Seperti yang dilakukan oleh narasumber peneliti yang bernama Yulianita ynag membuat iklan koran dan ditempatkan didalam iklan baris, akan tetapi menurutnya iklan ini kurang efektif karena pada waktu itu dirinya mengiklankan Oriflame dari segi bisnisnya bukan produknya. Terlebih lagi iklan baris yang letaknya sangat berdempetan dengan iklan yang lain. Jadi hanya orang-orang tertentu dan niat saja ynag akhirnya benar-benar dapat melihat iklan baris tersebut. 
Selain iklan baris tersebut, narasumber juga melakukan iklan online berupa iklan di facebook. Yulianita menganggap bahwa iklan yang dipasangnya di facebook efektif. Hal ini karena iklan ynag dipasang sudah sesuai dengan tujuan ynag hendak dicapainya yaitu tujuan merekrut downline. Banyak cara yang dapat dilakukan untuk berpromosi dengan media online. Mulai dengan iklan facebook, melalui blog ataupun juga dengan menggunakan web door way dengan memanfaatkan sistem autoresponder.

4. Promosi Penjualan

Banyak cara yang dilakukan oleh seorang konsultan agar calon pelanggan tertarik pada barang yang ditawarkannya. Berdasarkan hasil wawancara dengan beberapa konsultan, mereka cenderung lebih kepada kegiatan open table di bazaar, pemberian sampel, demonstrasi dan pemberian potongan atau diskon. Bazaar termasuk kedalam bentuk promosi penjualan karena ketika seorang konsultan membuka open table, konsultan dapat secara langsung bertatap muka dengan calon pelanggan tersebut, sedangkan bagi calon pelanggan, dengan adanya open table di Oriflame, calon pelanggan dapat dengan gratis mencoba produk Oriflame dan lebih meyakinkan calon pelanggan tentang kualitas produk Oriflame. Oriflame merupakan produk kosmetika yang hanya boleh dilakukan melalui konsultan. Produk Oriflame tidak dijual di toko, jadi jika seorang pelanggan ingin membeli produk Oriflame pelanggan harus mencari seorang konsultan Oriflame atau mendaftar terlebih dahulu mejadi seorang konsultan. Percobaan gratis seperti yang dilakukan ketika ada bazaar, dilakukan dengan cara mengundang calon pelanggan untuk mencoba produk secara gratis dengan harapan pelanggan akan membeli. Pemilihan acara bazaar juga harus melalui sebuah pertimbangan, yaitu harus sesuai dengan target pasar yang akan dicapai.

5. Acara dan Pengalaman

Acara dan pengalaman merupakan sebuah bentuk kegiatan ataupun program mensponsori sebuah acara, untuk menciptakan sebuah interaksi harian. Menurut Yulianita yang merupaka senior manager, mensponsori sebuah acara atau event merupaka wewenang perusahaan. Dimana konsultan hanya bertugas memaksimalkan saja.

6. $\quad$ Pemasaran Langsung (Direct Marketing)
Menurut Kotler dan Amstrong, (2003) dalam buku Dasar-Dasar Pemasaran. Direct marketing menggunakan iklan untuk menghubungkan antara pelanggan dengan penjual, dimana penjual tidak perlu mengunjungi toko ritel untuk membeli produk. Sama hal nya dengan Oriflame yang merupakan perusahaan multi level marketing yang pelanggan produknya harus melalui konsultannya karena tidak dijual di toko.

Pemasaran Oriflame dilakukan dengan katalog dengan menerapkan system multi level marketing. Dimana multi level marketing ini merupakan bagian dari direct marketing (www.apli.or.id). Penjualan menggunakan katalog ini dilakukan dengan bermacammacam cara, biasanya konsultan membagikan katalog lengkap dengan nomer telepon konsultan sehingga jika calon pelanggan ingin memesan bisa langsung menghubungi nomer telepon yang tertera.

Menurut Kotler, Philip dan Keller, Kevin Lane, (2008) dalam buku Manajemen Pemasaran. menyebutkan bahwa direct marketing mencakup beberapa bentuk pemasaran, antara lain : direct mail, catalog retailing, dan televised shopping. Direct mail ini dilakukan oleh konsultan dengan cara mengirimkan katalog kepada pelanggannya dan pelanggan memesan produk melalui telepon ataupun pesan (SMS). Pemasaran dengan direct selling ini bersifat lebih personal dan sesuai deng target konsumen yang hendak dituju dan hasilnya dapat diukur dengan cepat. Hal ini karena antara konsultan dan pelanggan sudah saling mengenal satu sama lain.

Menurut Kotler dan Amstrong, (2003) dalam buku Dasar-Dasar Pemasaran. Kegiatan direct marketing ini juga dapat terjadi ketika seorang konsultan mengadakan bazar. Hal ini karena produk Oriflame yang dipesan langsung oleh pelanggan dikirmkan langsung kerumah pelanggan. Dimana hal ini merupakan salah satu keunggulan dari sistem pemasaran direct marketing/direct selling. Selain bazaar, kegiatan direct selling dilakukan dengan seorang wiraniaga mengunjungi seseorang ynag menjadi tuan rumah dan mengundang teman-teman si tuan rumah, kemudian wiraniaga mendemonstrasikan produk dan mengambil pesanan.

7. Pemasaran Interaktif

Berupa kegiatan dan program online yang dirancang untuk melibatkan pelanggan atau prospek dan secara langsung atau tidak 
langsung meningkatkan kesadaran, memperbaiki citra, atau menciptakan penjualan produk dan jasa. Ada banyak program atau kegiatan online ynag dapat dilakukan untuk membangun suatu kegiatan pemasaran yang interaktif. Hal ini karena program online yang memiliki kelebihan daripada yang lain. Selain waktu yang fleksibel, tidak terikat waktu, online marketing ini tidak membutuhkan tempat kerja khusus. Artinya pebisnis dapat melakukan pekerjaannya dimana saja selama memiliki komputer yang terhubung dengan internet. Menurut penuturan Yulianita, alasannya bergabung dengan Oriflame karena dia dapat melakukan semua kegiatan pemasaran tanpa harus terikat dengan waktu dan tempat. Oleh karen itu, dengan adanya internet Yulianita lebih banyak menghabiskan waktunya untuk berjualan Oriflame dengan cara online, hal ini karena banyak kelebihan ynag ditawarkan dalam sistem pemasaran interaktif ini selain karena alasan tadi yaitu waktu dan tempat yang fleksibel. Pada pemasaran interaktif yang lebih mengandalkan sistem online ini kelebihan lainnya adalah seorang pemasar yaitu konsultan dapat melakukan kegiatan komunikasi pemasaran dengan jangkauan pelanggan yang lebih luas. Bisa dari seluruh Indonesia, bahkan seluruh dunia.

8. Pemasaran dari Mulut Ke Mulut

Menurut Kennedy, John E; R Dermawan Soemanagara, (2006) dalam buku Marketing Communication Taktik dan Strategi. Pemasaran ini berupa komunikasi secara lisan, tertulis, dan elektronik antar masyarakat yang berhubungan dengan keunggulan atau pengalaman membeli atau menggunakan produk atau jasa. Komunikasi ini dapat berlangsung dengan sebuah percakapan antar orang ke orang, chatroom, ataupun percakapan dengan menggunakan blog. Tidak hanya dengan bertatap muka langsung, pemasaran produk Oriflame juga dapat dilakukan dengan memanfaatkan blackberry messanger. Dimana disitu konsultan harus memiliki kemampuan berkomunikasi yang baik agar dapat dengan aktif mempromosikan Oriflame dan pelanggan dapat bertanya langsung kepada konsultan perihal produk maupun bisnis Oriflame.

\section{Penjualan Personal (Personal Selling)}

Penjualan personal (personal selling) lebih kepada komunikasi dengan cara bertatap muka langsung dengan pelanggan. Baik untuk memperkenalkan produk atau jasa maupun untuk menawarkan diri sebagai mitra bisnis. Kegiatan penjualan personal yang dilakukan oleh konsultan ini terjadi ketika Yulianita hadir dalam bazaar dan membuka open table untuk menawarkan produk Oriflame atau menawarkan mitra bisnis. Diharapkan dengan adanya komunikasi dengan cara bertatap muka langsung ini dapat membentuk pemahaman pelanggan terhadap produk sehingga mereka kemudian akan bertanya dan tertarik terhadap penawaran tersebut. Menurut Kennedy, John E; R Dermawan Soemanagara, (2006) dalam buku Marketing Communication Taktik dan Strategi. Penjualan personal meliputi kegiatan presentasi penjualan, rapat penjualan, program insentif, sampel dan pameran dagang. Sedangkan bentuk personal selling lainnya yaitu presentasi penjualan dilakukan oleh Yulianita dengan cara online. Hal ini dikarenakan latar belakang jaringannya yang lebih mengandalkan sistem online, yaitu jaringan d'BC Network.

Dari sekian banyak strategi yang ada, strategi yang paling banyak digunakan oriflame adalah personal selling yang menjual dan mencari langsung pelanggan dengan bertatap muka langsung sambil membagikan katalog dengan membuka kegiatan open table di bazaar.

\section{Multi Level Marketing Oriflame}

Multilevel marketing ( MLM ) adalah salah satu strategi pemasaran dengan membangun saluran distribusi, untuk memindahkan produk dan jasa langsung ke konsumen. Strategi seperti ini membuka sebuah peluang bagi seseorang yang ingin memiliki usaha sendiri atau wiraswasta. Strategi seperti ini tidak membutuhkan modal awal yang tinggi, Kebutuhan akan tempat usaha dan persediaan produk sudah disiapkan oleh perusahaan. Selain itu, ada tim manajemen yang siap membantu semua pekerjaan administrasi dari distributor. Strategi seperti ini membuat banyak orang yang dulunya tidak bisa memiliki bisnis sendiri, karena keterbatasan modal yang ada, akhirnya bisa menjadi pengusaha. Bisnis jaringan ini merupakan orang yang bergelut pada sebuah bisnis yang menekankan rekrutmen orang secara melebar atau horizontal mendalam vertikal untuk merekrut downline. Namun polanya tetap menjual, 
merekrut, dan mendidik atau melatih orang yang direkrut untuk melakukan hal yang sama. Menurut Yulianita, perusahaan multi level marketing saat ini masih dipandang negatif oleh beberapa masyarakat. Oleh karena itu, diperlukan adanya pencitraan agar dapat mengubah persepsi masyarakat terhadap MLM. Sehingga masyarakat dapat menerima apa ynag ditawarkan. Banyak hal yang dilakukan sebagai bentuk dari kegiatan pencitraan. Misal dengan memulai untuk membranding diri sehingga pelanggan dapat mempersepsi penjual dengan baik dan pelanggan dapat menerima produk yang dijual. Kegiatan pencitraan ini dapat dilakukan mulai dari facebook, twitter, status di blackberry messanger atau semua situs jejaring sosial ynag selalu di update dengan berisikan informasi-informasi terkait dengan Oriflame beserta kelebihan-kelebihan jika bergabung menjadi konsultan Oriflame. Misalnya di twitter. Kegiatan pencitraan melalui twitter ini dapat berupa updatean twit yang dilakukan oleh seorang konsultan. Dimana disetiap twit yang dituliskan digambarkan hal-hal positif terhadap Oriflame maupun untuk konsultan itu sendiri.

Dimana sebelumnya image yang melekat pada perusahaan Multi Level Marketing adalah image negatif. Selain di twitter, kegiatan pencitraan dilakukan di halaman facebook. Hal ini dapat dilihat mulai dari foto sampul pada kronologi facebook sampai dengan update-tan status facebook yang ditulis oleh konsultan.

Bisnis Multi Level Marketing Oriflame tidak hanya dapat tampil luar biasa dan bersenangsenang tetapi juga dapat menghasilkan uang dengan menghemat dari pembelian atas produk-produk Oriflame. Menurut buku "Inilah Oriflame The Opportunity Presentation", dengan menjadi Consultant Oriflame kita bisa menghemat dalam membeli produk dengan sedikitnya diskon $23 \%$ dan kita akan menghasilkan lebih banyak uang hingga 21\% atas penjualan tim dengan mengajak orang bekerja bersama sebagai tim. Semakin besar tim, semakin besar pula penghasilan. Karena di Oriflame kita lah yang menjadi bos kita sendiri. Didalam usaha oriflame ini sudah pasti seluruh orang bisa memulainya asalkan ada kemauan dan kerja keras, dikarenakan bisnis MLM ini untuk memulainya tidak memerlukan modal yang cukup besar, tetapi model usaha ini hanya mengeluarkan sedikit modal ynag biasanya adalah biaya pendaftaran untuk bergabung dalam anggota jaringan pemasaran MLM tersebut.

\section{Kepercayaan Distributor sebagai Mitra Usaha}

\section{Kepercayaan}

Kepercayaan adalah kemauan seseorang untuk bertumpu pada orang lain dimana kita memiliki keyakinan padanya. Kepercayaan merupakan kondisi mental yang didasarkan oleh situasi seseorang dan konteks sosialnya. Ketika seseorang mengambil keputusan, ia akan lebih memilih keputusan berdasarkan pilihan dari orang-orang yang lebih dapat ia percaya daripada yang kurang dipercayainya (Moorman,1993).

Menurut Rousseau et al, (1998) kepercayaan adalah wilayah psikologis yang merupakan perhatian untuk menerima apa adanya berdasarkan harapan terhadap perilaku yang baik dari orang lain. Kepercayaan konsumen didefinisikan sebagai kesediaan satu pihak untuk menerima resiko dari tindakan pihak lain berdasarkan harapan bahwa pihak lain akan melakukan tindakan penting untuk pihak yang mempercayainya, terlepas dari kemampuan untuk mengawasi dan mengendalikan tindakan pihak yang dipercaya.

Menurut dokumen perusahaan dalam buku Inilah Oriflame, The Opportunity Presentitation. Oriflame berusaha agar bisa terus meningkatkan kepercayaan distributor sebagai mitra usahanya dengan 3 hal yakni: 1 . Luar biasa yaitu bisnis oriflame bisa dikerjakan dimana saja dengan modal rendah dan dapat mempertemukan distributor dengan teman baru dari berbagai kalangan dan akan banyak ilmu yang didapat dari berbagai acara seminar dan beauty class yang diadakan oleh oriflame serta semua impian akan menjadi nyata dengan menaiki tangga level yang berikutnya. 2 . Menghasilkan uang yaitu distributor akan mendapatkan keuntungan 23\% dari harga katalog dan 30\% dari penjualan kelompok/tim dan distributor akan mendapatkan komisi setiap bulannya. 3. Bersenang-senang yaitu distributor akan dimanjakan dengan berbagai fasilitas gratis dan liburan gratis dari mulai dalam negeri sampai liburan ke luar negeri gratis untuk kualifikasi distributor yang berprestasi. Oleh karena itu, semua distributor yang bergabung dengan oriflame memiliki 
banyak keuntungan dan kesempatan yang sama untuk bisa sukses bersama.

Sehingga dapat disimpulkan bahwa kepercayaan konsumen adalah kesediaan satu pihak menerima resiko dari pihak lain berdasarkan keyakinan dan harapan bahwa pihak lain akan melakukan tindakan sesuai yang diharapkan meskipun kedua belah pihak belum mengenal satu sama lain.

\section{Distributor}

Distributor atau dealer dalam hal ini dapat berupa perantara, grosir, pengecer, penjual langsung, importer, atau eksportir, dan rangkaian distribusi yang digunakan oleh perusahaan atau pemasok. Barang dan jasa akan didistribusikan dengan cara yang efisien dan menguntungkan, karena distributor mengharapkan keuntungan dari hasil memenuhi permintaan dengan persediaan yang cukup.

Distributor pada dasarnya merupakan perantara yang menjembatani antara produsen dan konsumen. Perantara tersebut dapat digolongkan kedalam dua golongan yaitu: Pedagang perantara dan Agen perantara. Perbedaannya terletak pada aspek pemilikan serta proses negosiasi dalam pemindahan produk yang disalurkan tersebut.

1. Pedagang perantara, pada dasarnya pedagang perantara (merchant middleman) ini bertanggung jawab terhadap pemilikan semua barang yang dipasarkannya atau dengan kata lain pedagang mempunyai hak atas kepemilikan barang.

2. Agen perantara, (Agen middleman) ini tidak mempunyai hak milik atas semua barang yang mereka tangani. Mereka dapat digolongkan kedalam dua golongan, yaitu : Agen penunjang dan Agen pelengkap.

Pada umumnya, produk dan jasa ditangani oleh distributor karena penjualannya didukung oleh periklanan bukan berarti satu-satunya sarana pendukung pemasaran, sebab iklan mempunyai keterbatasan daya jangkau.

Distribusi adalah suatu proses penyampaian barang atau jasa dari produsen kepada konsumen dan para pemakai, sewaktu dan dimana barang atau jasa tersebut diperlukan. Proses distribusi tersebut pada dasarnya menciptakan faedah (utility) waktu, tempat, dan pengalihan hak milik. Menurut Winardi, (1989) dalam buku Strategi Pemasaran yang dimaksud dengan saluran distribusi adalah suatu kelompok perantara yang berhubungan erat satu sama lain dan yang menyalurkan produk-produk kepada pembeli.

Kepercayaan distributor sebagai mitra usaha harus dijaga dan dipertahankan karena menurut peneliti kepercayaan mitra usaha dalam hal ini distributor adalah ujung tombak kesuksesan oriflame karena mitra usaha berpengaruh dalam menciptakan brand image oriflame yang sesuai visi nya tahun ini adalah menaikan standar kerja dan profesionalisme menjadi yang terbaik yang ia bisa.

\section{Mitra Usaha}

Menurut Peraturan Pemerintah Nomor 44 Tahun 1997 (Bab 1 pasal 1) Kemitraan adalah kerjasama usaha antara usaha kecil dengan usaha menengah dan atau dengan usaha besar disertai pembinaan dan pengembangan oleh usaha menenah dan atau usaha besar dengan memperhatikan prinsip saling memerlukan, saling memperkuat dan saling menguntungkan. Berdasarkan kutipan diatas, kemitraan mencakup kerjasama yang saling menguntungkan antara bentuk usaha kecil dan usaha menengah dan usaha besar. Dalam hal ini usaha kecil adalah kegiatan ekonomi rakyat berskala kecil yang mempunyai kriteria sebagaimana diatur dalam Pasal 5 Undangundang Nomor Tahun 1995 tentang usaha kecil. Usaha besar dan menengah adalah kegiatan ekonomi yang memiliki kriteria kekayaan bersih atau hasil penjualan tahunan lebih besar daripada kekayaan bersih atau hasil penjualan tahunan usaha kecil. Menurut Undang-undang Nomor 18 Tahun 1999 Tentang Jasa Konstruksi "Asas kemitraan mengandung pengertian hubungan kerja para pihak yang harmonis, terbuka, bersifat timbal balik dan sinergia".

Kebanyakan produsen, dalam menyalurkan produk-produk mereka ke pasar perlu bekerjasama dengan para perantara pemasaran. Perantara ini yang disebut mitra usaha, para mitra usaha ini akan membentuk saluran distribusi langsung kepada konsumen. Pemilihan mitra usaha ini pada umumnya didasarkan kepada pertimbanganpertimbangan ekonomis yang saling memberikan keuntungan. Potensi kerjasama 
ini dapat dikembangakan dengan berbagai upaya antaralain dengan adanya kesamaan sasaran atau kepentingan. Produsen, dan para mitra usaha saling mengisi kebutuhan masingmasing, bisa mengenal, melayani dan memuaskan pasar sasaran lebih efisien dan efektif dibanding harus bekerja sendiri-sendiri.

\section{Kerangka Pemikiran}

Strategi komunikasi pemasaran multilevel marketing oriflame dalam meningkatkan kepercayaan distributor sebagai mitra usaha memiliki dua variabel yaitu strategi komunikasi pemasaran termasuk variabel bebas (x) dengan 4 indikator yaitu: Produk (product) yang kategori nya adalah kualitas produk, ciri produk dan desain produk. Penetapan Harga (price) yang kategorinya adalah harga terjangkau, kompetitif, dan diskon. Tempat (place) yang kategorinya adalah ruangan SPO strategis dan kenyamanan. Promosi (promotion) yang kategorinya adalah personal selling, bazaar dan katalog.

Sedangkan kepercayaan distributor sebagai mitra usaha termasuk variabel terikat (y) yang mempunyai kategori yaitu luar biasa, menghasilkan uang dan bersenang-senang.

\section{Gambar 1. Alur Kerangka Pemikiran}

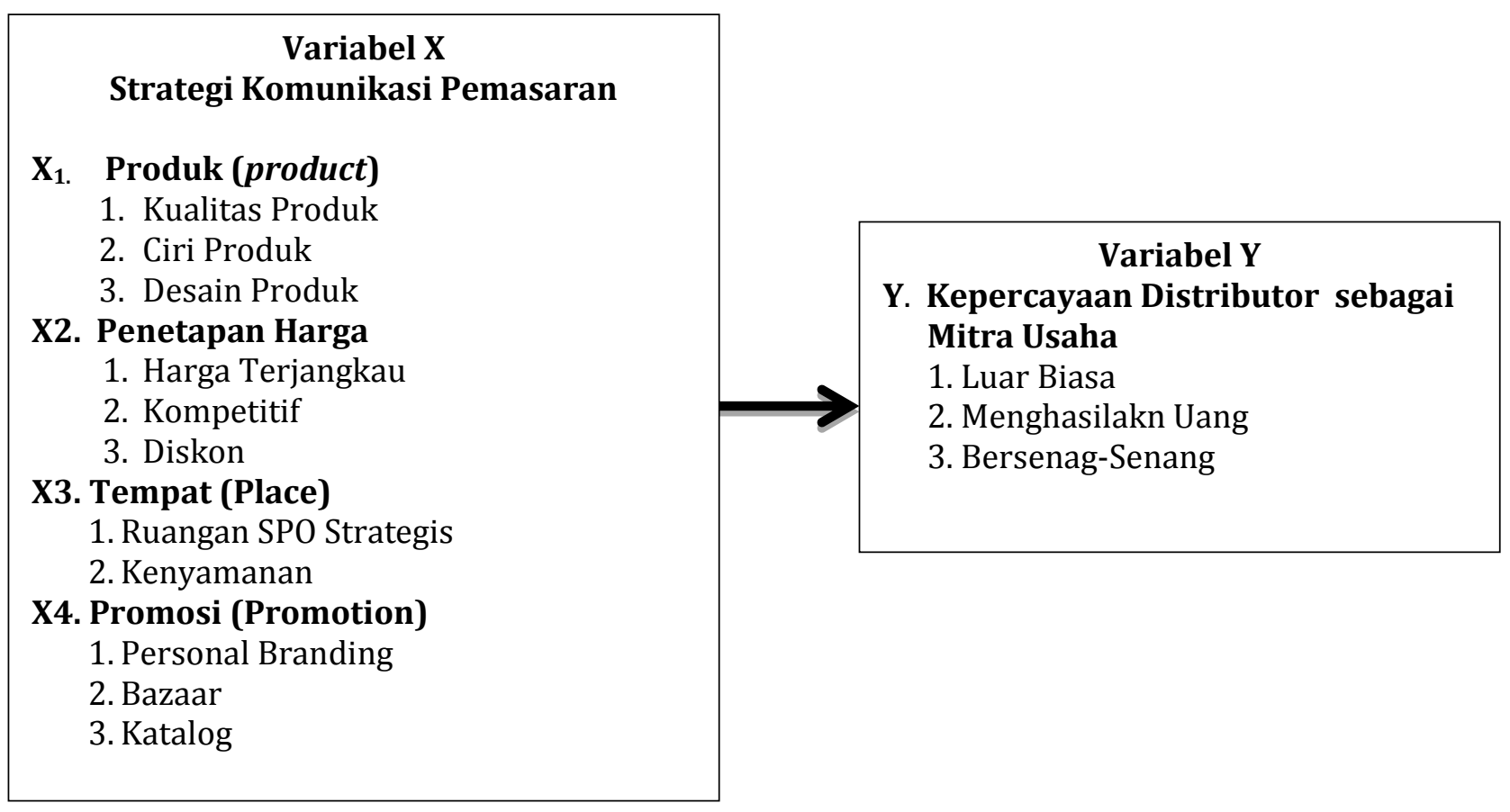

\section{Hipotesis}

Hipotesis dalam penelitian ini merupakan jawaban sementara terhadap rumusan masalah pada suatu penelitian (Sugiyono, 2009). Hipotesis yang diajukan peneliti adalah :

Ha : Strategi komunikasi pemasaran multi level marketing Oriflame berpengaruh terhadap kepercayaan distributor sebagai mitra usaha.
Ho : Strategi komunikasi pemasaran multi level marketing Oriflame tidak berpengaruh terhadap kepercayaan distributor sebagai mitra usaha. 


\section{MATERI DAN METODE}

\section{Jenis Penelitian}

Metode yang digunakan dalam penelitian ini adalah metode deskriptif korelasional yaitu, menggambarkan tentang pengaruh strategi komunikasi pemasaran multi level marketing Oriflame terhadap kepercayaan mitra usaha. Dengan demikian, penelitian ini menunjukan strategi komunikasi pemasaran sebagai variabel bebas (pendukung) berpengaruh terhadap kepercayaan mitra usaha untuk menghimpun data, menyusunnya secara sistematis, factual, dan cermat (Isaac dan Michael 1981).

Pendekatan dalam penelitian ini adalah kuantitatif. Kuantitatif adalah riset yang menggambarkan atau menjelaskan suatu masalah yang hasilnya dapat digeneralisasikan. Dengan demikian tidak terlalu mementingkan kedalaman data atau analisis.

\section{Penetapan Lokasi dan Obyek Penelitian}

Lokasi penelitian ini di SPO-1088 Bogor Center Taman Topi Square Lantai Ground Blok E No.15. SPO Oriflame sebagai lokasi penelitian yang melakukan banyak training kepada distributor dilihat berdasarkan strategi komunikasi pemasaran terhadap kepercayaan mitra usaha. Bahwa strategi komunikasi merupakan ujung tombak terciptanya kualitas kepercayaan mitra usaha.

\section{Sampel}

Sampel adalah sebagian dari jumlah dan karakteristik yang dimilki oleh populasi tersebut (Sugiyono,2009). Selanjutnya digunakan rumus Yamane dengan tingkat presisi ditentukan 5\% dengan tingkat kepercayaan 95\%, menurut (Sugiyono,1999) sebagai berikut :

$$
n=\frac{N}{N \cdot d^{2}+1}
$$

Keterangan :

$$
\begin{aligned}
& \text { n : Jumlah Sampel } \\
& \mathrm{N} \quad \text { : Ukuran Populasi } \\
& \text { d : Presisi (perkiraan kesalahan yang } \\
& \text { diperkenankan yaitu 5\%) }
\end{aligned}
$$

Penarikan sampel dilakukan dengan teknik accidental sampling. Artinya, teknik penentuan sampel berdasarkan kebetulan, yaitu siapa saja yang secara kebetulan bertemu dengan peneliti dapat digunakan sebagai sampel, bila dipandang orang yang kebetulan ditemui itu cocok dengan sumber data (Sugiyono,2002). Jumlah yang diambil sebagai sample sebanyak 45 distributor.

\section{Teknik Pengumpulan Data}

Pengumpulan data pada dasarnya merupakan bagian dari suatu kegiatan operasional peneliti, pengumpulan data tidak hanya sebagai aktivitas penelitian ynag sifatnya kebetulan saja, akan tetapi dalam hal ini dilakukan upayaupaya untuk menghimpun data secara sistematis dan terencana. Teknik pengumpulan data yang dilakukan dalam penelitian ini bersumber dari data primer maupun sekunder, yaitu sebagai berikut :

1. Data Sekunder

Data sekunder adalah data dari sumbersumber tertulis yang bersifat teoritis dan berhubungan sengan bidang yang diteliti seperti buku, majalah, dokumen, dan berbagai macam literature yang berhubungan dengan penelitian ini dilakukan.

\section{Data Primer}

Data primer adalah data yang didapatkan dari penelitian langsung dilapangan. Prosedur pengumpulan data dalam penelitian ini, dapat dilakukan melalui langkah-langkah sebagai berikut :

a. Melakukan observasi, yaitu pengumpulan data dengan mengadakan pengamatan langsung terhadap objek yang diteliti, dengan tujuan untuk mengetahui keadaan sesungguhnya.

b. Melakukan wawancara dengan orang-orang yang terkait dengan masalah yang diteliti, agar dapat mengungkap fakta yang terjadi di lapangan.

c. Menyebarkan kuesioner kepada responden. Bentuk kuesioner yang digunakan bersifat tertutup, artinya pilihan jawaban atas pertanyaan telah ditentukan sebelumnya oleh peneliti. Skala pengukuran data yang digunakan dalam penelitian ini adalah skala Likert. "Untuk mengukur sikap, pendapat dan persepsi seseorang atau kelompok orang tentang fenomena sosial diukur dengan skala Likert". Sugiyono, (2000). Dimana jawaban dari setiap instrument penelitian yang digunakan mempunyai gradasi dari sangat positif sampai sangat negative. Singarimbun, (1995) mengemukakan bahwa dengan 
menggunakan "Skala Likert", cara pengukurannya adalah dengan menghadapkan seorang responden dengan sebuah pertanyaan dan kemudian diminta untuk memberi jawaban "Sangat setuju", "Setuju", "Cukup Setuju", "Tidak setuju", "Sangat tidak setuju".

\section{HASIL DAN PEMBAHASAN}

\section{Gambaran Umum Oriflame}

Oriflame berasal dari Swedia yang didirikan tahun 1967 oleh Jonas dan Robert af Jochnick. Semuanya berawal dari sebuah runag kantor sederhana di pusat kota Stockhholm. Robert dan Jonas af Jochnick bermimpi ingin memberi banyak orang kesempatan untuk memperoleh manfaat dari perawatan kulit yang baik dan kosmetika berkualitas tinggi ynag terinspirasi dari keindahan alam Swedia.

Terobosan luar biasa yang dilakukan oleh dua bersaudara af Jochnick adalah memindahkan mata rantai bisnis Oriflame kerumah konsumen. Segera saja, Oriflame memiliki konsultan penjualan diseluruh negeri dan masing-masing setiap satu dari mereka memiliki hati dan ambisi dari seorang pengusaha. Dan hingga saat ini oriflame telah menjadi perusahaan kecantikan internasional dengan sistem penjualan langsung dilebih dari 61 negara di seluruh dunia (salah satunya Indonesia), Portofolio yang luas dari 800 produk-produk kecantikan Swedia yang alami, inovatif dipasarkan melalui tenaga penjualan sekitar 3.600.000 Consultant mandiri, dengan 100 juta katalog dalam 35 bahasa yang bersama-sama membuat penjualan tahunan melebihi $€ 1,5$ miliar.

Oriflame (PT.Orindo Alam Ayu) terdaftar sebagai anggota Assosiasi Penjualan Langsung Indonesia (APLI) dengan nomor anggota : 0011/06/93. Di Indonesia sendiri, Oriflame didirikan sejak tahun 1986 dan telah berjaya di Indonesia selama 23 tahun. Ribuan konsultan dan 12 kantor cabang Oriflame telah tersebar di seluruh Indonesia. Dari 61 negara yang ada Oriflame, Indonesia berada di peringkat keenam yang berkembang dengan pesat.

Menghormati orang dan alam mendasari prinsip operasional perusahaan dan tercermin dalam kebijakan sosial dan lingkungan. Oriflame mendukung berbagai badan amal di seluruh dunia dan merupakan Co-founder World Childhood Foundation. Oriflame Cosmetics terdaftar di Nasdaq OMX Nordic Exchange.

\section{Visi dan Misi Oriflame}

Visi Oriflame adalah untuk menjadi perusahaan penjual produk kecantikan nomor 1 yang menjalankan penjualan secara langsung. Adapun Misi Oriflame adalah mewujudkan impian. Oriflame menawarkan peluang bisnis terkemuka untuk orang-orang yang ingin mulai membuat uang sejak hari pertama dan bekerja untuk memenuhi impian dan ambisi pribadi mereka melalui konsep bisnis yang unik yakni "Make money today and fulfil your dreams tomorrow".

\section{Lambang Oriflame}

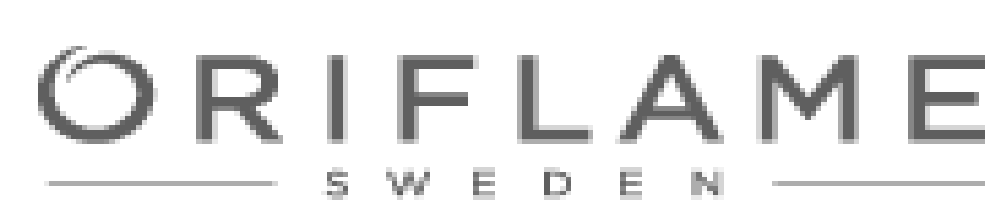

\section{Struktur Organisasi Oriflame Berdasarkan Level Pendapatan}

Consultant: 0\% - 9\%, Manager: 12\% - 18\%, Senior Manager: Diploma, Director: Rp. 7 juta,
Gold Director: Rp. 14 juta, Senior Gold Director: Rp. 21 juta, Sapphire Director: Rp. 28 juta, Diamond Director: Rp. 42 juta, Senior Diamond Director: Rp. 56 juta, Executive Director: Rp. 70 juta, Gold Executive Director: Rp. 168 juta, 
Sapphire Executive Director: Rp. 210 juta, Diamond Executive Director: Rp. 252 juta, President Director: Rp. 294 juta, Senior President Director: Rp. 700 juta, Gold President Director: Rp. 1,4 Milyar, Sapphire President Director: Rp. 2,1 Milyar, Diamond President Director: Rp. 7 Milyar.

\section{Karakteristik Distributor Oriflame SPO Taman Topi Square}

Sebelum mengetahui lebih lanjut penelitian di lapangan, perlu diketahui karakteristik Tabel 1. Distribusi karakteristik distributor Oriflame berdasarkan jenis kelamin, usia, pendidikan dan pekerjaan di SPO Taman Topi Square. distributor SPO di Taman Topi Square menjadi objek penelitian. Distributor yang menjadi mendatangi SPO. Hal tersebut karena peneliti ingin mengetahui strategi komunikasi pemasaran multilevel marketing oriflame dalam meningkatkan kepercayaan distributor sebagai mitra usaha.

Untuk mengetahui Jenis Kelamin, Usia, Pendidikan dan Pekerjaan dapat dilihat pada tabel berikut ini : objek penelitian adalah distributor yang

\begin{tabular}{|c|c|c|c|}
\hline No & Jenis Kelamin, Usia, Pendidikan dan Pekerjaan & $\mathbf{f}$ & $\%$ \\
\hline \multirow[t]{4}{*}{1} & \multicolumn{3}{|l|}{ Jenis Kelamin } \\
\hline & Laki-laki & 10 & $22 \%$ \\
\hline & Perempuan & 35 & $78 \%$ \\
\hline & Total & 45 & $100 \%$ \\
\hline \multirow[t]{6}{*}{2} & \multicolumn{3}{|l|}{ Usia } \\
\hline & $<20$ Tahun & 12 & $27 \%$ \\
\hline & 20-29 Tahun & 10 & $22 \%$ \\
\hline & 30-39 Tahun & 12 & $27 \%$ \\
\hline & $>40$ Tahun & 11 & $24 \%$ \\
\hline & Total & 45 & $100 \%$ \\
\hline \multirow[t]{7}{*}{3} & \multicolumn{3}{|l|}{ Pendidikan } \\
\hline & SD & 2 & $4 \%$ \\
\hline & SLTP & 7 & $16 \%$ \\
\hline & SLTA & 28 & $62 \%$ \\
\hline & Sarjana & 8 & $18 \%$ \\
\hline & Pasca Sarjana & 0 & $0 \%$ \\
\hline & Total & 45 & $100 \%$ \\
\hline \multirow[t]{7}{*}{4} & \multicolumn{3}{|l|}{ Pekerjaan } \\
\hline & Pelajar/Mahasiswa & 14 & $31 \%$ \\
\hline & Pegawai Negeri & 3 & $7 \%$ \\
\hline & Karyawan Swasta & 8 & $18 \%$ \\
\hline & Wirasaswasta & 11 & $24 \%$ \\
\hline & $\begin{array}{l}\text { Professional (Dokter, Konsultan, Kontraktor dan ibu } \\
\text { rumah tangga) }\end{array}$ & 9 & $20 \%$ \\
\hline & Total & 45 & $100 \%$ \\
\hline
\end{tabular}

Sumber : Pengolahan data primer, 2014

Berdasarkan data pada tabel diatas, diketahui bahwa sebagian besar distributor Oriflame di SPO Taman Topi Square yang menjadi responden berjenis kelamin perempuan (78\%) dan selebihnya laki-laki (22\%). Usia distributor terdiri atas usia <20 Tahun (27\%), usia 20-29 Tahun (22\%), usia 30-39 Tahun (27\%) sedangkan usia $>40$ Tahun (24\%). Apabila dilihat dari tingkat pendidikan distributor sebagian besar berpendidikan SLTA (62\%) dan
Sarjana (18\%), sedangkan yang lainnya SLTP (7\%) dan SD (4\%). Selanjutnya dilihat dari pekerjaannya, sebagian besar distributor Oriflame adalah pelajar (31\%) dan wiraswasta (24\%), selebihnya adalah Ibu Rumah Tangga (20\%), karyawan swasta (24\%) dan Pegawai negeri (7\%).

\section{Distribusi Variabel Penelitian}


Sebelum menguji hipoteseis, maka data primer yang telah terkumpul dari hasil penelitian yang dilakukan terhadap jumlah distributor di SPO Taman Topi Square yaitu sebanyak 50 distributor, sehingga menjadi 45 distributor yang diambil secara accidental. Sedangkan jawaban tersebut disajikan dalam bentuk tabulasi yang berupa pernyataan yang terstruktur dengan didasarkan pada kategori dari masing-masing indikator variabel sebagai berikut:

\section{Strategi Komunikasi Pemasaran Multi Level Marketing Oriflame}

Tabel 2. Distribusi distributor SPO Taman Topi Square berdasarkan Strategi Komunikasi Pemasaran

Multi Level Marketing Oriflame ( $\mathrm{n}=45)$

\begin{tabular}{|c|c|c|c|c|c|c|c|}
\hline No & $\begin{array}{l}\text { Strategi Komunikasi } \\
\text { Pemasaran Oriflame }\end{array}$ & $\begin{array}{l}\text { Tanggapan } \\
\text { Distributor }\end{array}$ & $\mathbf{f}$ & $(x)$ & $f(x)$ & $\%$ & $\Sigma f(x) / n$ \\
\hline \multicolumn{8}{|c|}{ Produk Oriflame } \\
\hline \multicolumn{8}{|c|}{ 1. Kualitas Produk } \\
\hline \multirow[t]{6}{*}{1} & \multirow{6}{*}{$\begin{array}{l}\text { Memanfaatkan bahan } \\
\text { alami dari tumbuhan. }\end{array}$} & Sangat Baik & 21 & 5 & 105 & $47 \%$ & \multirow[t]{6}{*}{4,28} \\
\hline & & Baik & 22 & 4 & 88 & $49 \%$ & \\
\hline & & Cukup Baik & 2 & 3 & 6 & $4 \%$ & \\
\hline & & Tidak Baik & 0 & 2 & 0 & $0 \%$ & \\
\hline & & Sangat Tidak Baik & 0 & 1 & 0 & $0 \%$ & \\
\hline & & Jumlah & 45 & & 193 & $100 \%$ & \\
\hline \multirow[t]{6}{*}{2} & \multirow{6}{*}{$\begin{array}{l}\text { Aman dan sehat bagi } \\
\text { semua jenis kulit. }\end{array}$} & Sangat Baik & 18 & 5 & 90 & $40 \%$ & \multirow[t]{6}{*}{4,35} \\
\hline & & Baik & 25 & 4 & 100 & $56 \%$ & \\
\hline & & Cukup Baik & 2 & 3 & 6 & $4 \%$ & \\
\hline & & Tidak Baik & 0 & 2 & 0 & $0 \%$ & \\
\hline & & Sangat Tidak Baik & 0 & 1 & 0 & $0 \%$ & \\
\hline & & Jumlah & 45 & & 196 & $100 \%$ & \\
\hline \multirow[t]{6}{*}{3} & \multirow{6}{*}{$\begin{array}{l}\text { Dapat digunakan oleh } \\
\text { kaum muslim. }\end{array}$} & Sangat Baik & 23 & 5 & 115 & $51 \%$ & \multirow[t]{6}{*}{4,48} \\
\hline & & Baik & 21 & 4 & 84 & $47 \%$ & \\
\hline & & Cukup Baik & 1 & 3 & 3 & $2 \%$ & \\
\hline & & Tidak Baik & 0 & 2 & 0 & $0 \%$ & \\
\hline & & Sangat Tidak Baik & 0 & 1 & 0 & $0 \%$ & \\
\hline & & Jumlah & 45 & & 202 & $100 \%$ & \\
\hline \multirow[t]{6}{*}{4} & \multirow{6}{*}{$\begin{array}{l}\text { Terbuat tanpa bahan } \\
\text { kimia. }\end{array}$} & Sangat Baik & 14 & 5 & 70 & $31 \%$ & \multirow[t]{6}{*}{4,27} \\
\hline & & Baik & 29 & 4 & 116 & $65 \%$ & \\
\hline & & Cukup Baik & 2 & 3 & 6 & $4 \%$ & \\
\hline & & Tidak Baik & 0 & 2 & 0 & $0 \%$ & \\
\hline & & Sangat Tidak Baik & 0 & 1 & 0 & $0 \%$ & \\
\hline & & Jumlah & 45 & & 192 & $100 \%$ & \\
\hline \multicolumn{8}{|c|}{ Angka Penafsiran $(4,28+4,35+4,48+4,27) / 4=4,34$} \\
\hline \multicolumn{8}{|c|}{ 2. Ciri Produk Oriflame } \\
\hline \multirow[t]{4}{*}{5} & \multirow{4}{*}{$\begin{array}{l}\text { Menggemari aroma } \\
\text { bunga dan buah. }\end{array}$} & Sangat Baik & 17 & 5 & 85 & $38 \%$ & \multirow[t]{4}{*}{4,33} \\
\hline & & Baik & 26 & 4 & 104 & $58 \%$ & \\
\hline & & Cukup Baik & 2 & 3 & 6 & $4 \%$ & \\
\hline & & Tidak Baik & 0 & 2 & 0 & $0 \%$ & \\
\hline
\end{tabular}

Strategi komunikasi pemasaran multi level marketing oriflame yang dimaksud adalah bagaimana strategi komunikasi pemasaran yang diberikan kepada distributor. Adapun indikator dari strategi komunikasi pemasaran multi level marketing oriflame yaitu produk, harga, tempat, promosi diukur dengan menggunakan "Skala Likert" yang datanya masih skala ordinal/primer. Untuk mengukur hasil penelitian tersebut dapat dilihat dari tabel berikut. 


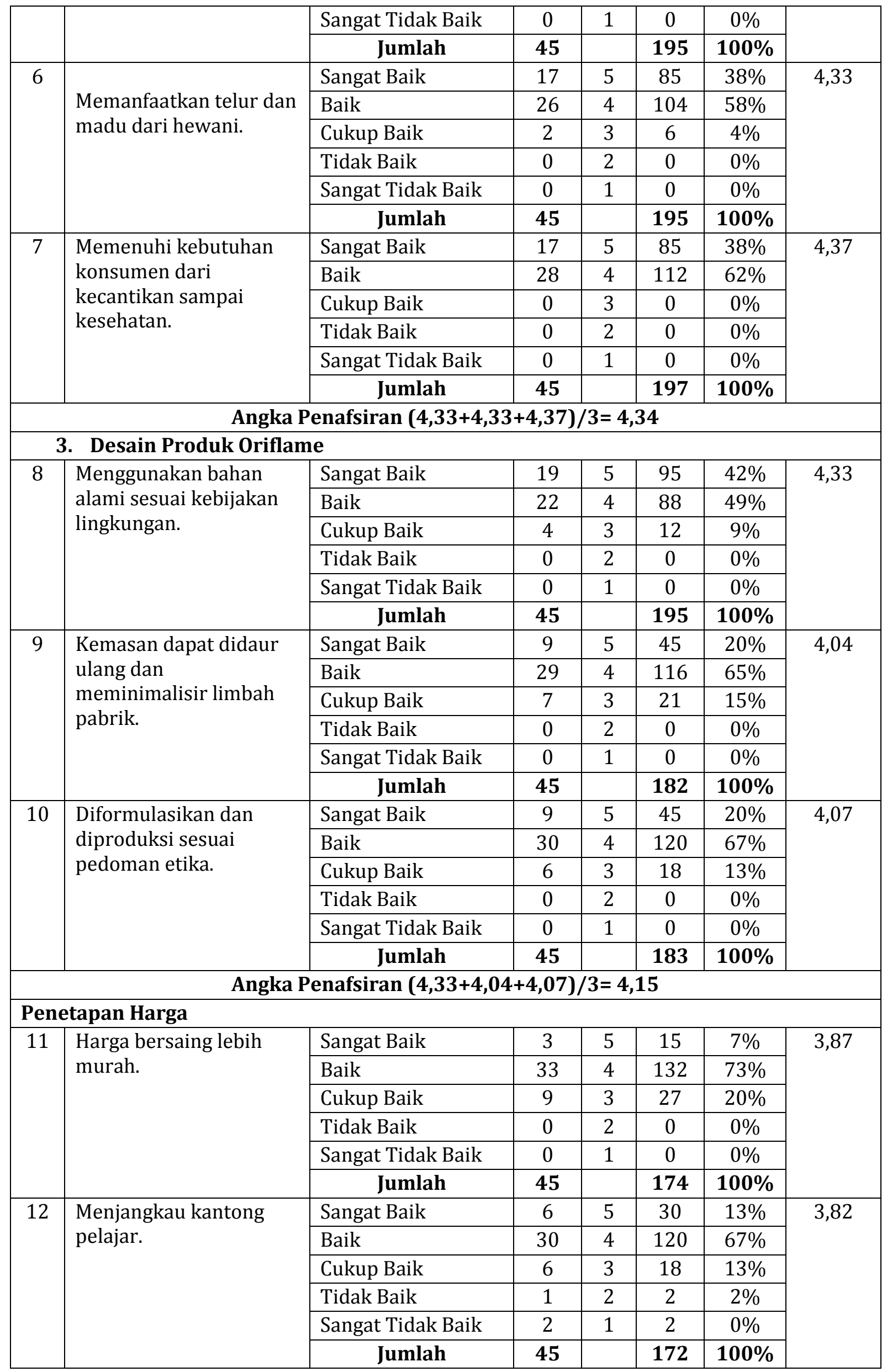




\begin{tabular}{|c|c|c|c|c|c|c|c|}
\hline \multirow[t]{6}{*}{13} & \multirow[t]{6}{*}{ Diskon. } & Sangat Baik & 10 & 5 & 50 & $22 \%$ & \multirow[t]{6}{*}{4,13} \\
\hline & & Baik & 31 & 4 & 124 & $69 \%$ & \\
\hline & & Cukup Baik & 4 & 3 & 12 & $9 \%$ & \\
\hline & & Tidak Baik & 0 & 2 & 0 & $0 \%$ & \\
\hline & & Sangat Tidak Baik & 0 & 1 & 0 & $0 \%$ & \\
\hline & & Jumlah & 45 & & 186 & $100 \%$ & \\
\hline \multirow[t]{6}{*}{14} & \multirow{6}{*}{$\begin{array}{l}\text { Harga murah } \\
\text { mendapatkan kualitas } \\
\text { baik. }\end{array}$} & Sangat Baik & 7 & 5 & 35 & $16 \%$ & \multirow[t]{6}{*}{3,73} \\
\hline & & Baik & 27 & 4 & 108 & $60 \%$ & \\
\hline & & Cukup Baik & 4 & 3 & 12 & $9 \%$ & \\
\hline & & Tidak Baik & 6 & 2 & 12 & $13 \%$ & \\
\hline & & Sangat Tidak Baik & 1 & 1 & 1 & $2 \%$ & \\
\hline & & Jumlah & 45 & & 168 & $100 \%$ & \\
\hline \multicolumn{8}{|c|}{ Angka Penafsiran $(3,87+3,82+4,13+3,73) / 4=3,89$} \\
\hline \multicolumn{8}{|c|}{ Gedung/Ruangan SPO } \\
\hline \multirow[t]{6}{*}{15} & \multirow{6}{*}{$\begin{array}{l}\text { SPO mempermudah } \\
\text { order. }\end{array}$} & Sangat Baik & 17 & 5 & 85 & $38 \%$ & \multirow[t]{6}{*}{4,22} \\
\hline & & Baik & 21 & 4 & 84 & $47 \%$ & \\
\hline & & Cukup Baik & 7 & 3 & 21 & $15 \%$ & \\
\hline & & Tidak Baik & 0 & 2 & 0 & $0 \%$ & \\
\hline & & Sangat Tidak Baik & 0 & 1 & 0 & $0 \%$ & \\
\hline & & Jumlah & 45 & & 190 & $100 \%$ & \\
\hline \multirow[t]{6}{*}{16} & \multirow{6}{*}{$\begin{array}{l}\text { Gedung mencukupi } \\
\text { untuk training. }\end{array}$} & Sangat Baik & 13 & 5 & 65 & $29 \%$ & \multirow[t]{6}{*}{4,20} \\
\hline & & Baik & 28 & 4 & 112 & $62 \%$ & \\
\hline & & Cukup Baik & 4 & 3 & 12 & $9 \%$ & \\
\hline & & Tidak Baik & 0 & 2 & 0 & $0 \%$ & \\
\hline & & Sangat Tidak Baik & 0 & 1 & 0 & $0 \%$ & \\
\hline & & Jumlah & 45 & & 189 & $100 \%$ & \\
\hline \multirow[t]{6}{*}{17} & \multirow[t]{6}{*}{ Kenyamanan SPO. } & Sangat Baik & 16 & 5 & 80 & $35 \%$ & \multirow[t]{6}{*}{4,29} \\
\hline & & Baik & 26 & 4 & 104 & $58 \%$ & \\
\hline & & Cukup Baik & 3 & 3 & 9 & $7 \%$ & \\
\hline & & Tidak Baik & 0 & 2 & 0 & $0 \%$ & \\
\hline & & Sangat Tidak Baik & 0 & 1 & 0 & $0 \%$ & \\
\hline & & Jumlah & 45 & & 193 & $100 \%$ & \\
\hline \multicolumn{8}{|c|}{ Angka Penafsiran $(4,22+4,20+4,29) / 3=4,34$} \\
\hline \multicolumn{8}{|c|}{ Promosi Oriflame } \\
\hline \multirow[t]{6}{*}{18} & \multirow[t]{6}{*}{ Open table bazaar } & Sangat Baik & 12 & 5 & 60 & $27 \%$ & \multirow[t]{6}{*}{4,13} \\
\hline & & Baik & 27 & 4 & 108 & $60 \%$ & \\
\hline & & Cukup Baik & 6 & 3 & 18 & $13 \%$ & \\
\hline & & Tidak Baik & 0 & 2 & 0 & $0 \%$ & \\
\hline & & Sangat Tidak Baik & 0 & 1 & 0 & $0 \%$ & \\
\hline & & Jumlah & 45 & & 186 & $100 \%$ & \\
\hline 19 & Personal selling dalam & Sangat Baik & 7 & 5 & 35 & $16 \%$ & 4,06 \\
\hline & melakukan promosi. & Baik & 34 & 4 & 136 & $75 \%$ & \\
\hline & & Cukup Baik & 4 & 3 & 12 & $9 \%$ & \\
\hline & & Tidak Baik & 0 & 2 & 0 & $0 \%$ & \\
\hline & & Sangat Tidak Baik & 0 & 1 & 0 & $0 \%$ & \\
\hline & & Jumlah & 45 & & 183 & $100 \%$ & \\
\hline 20 & Personal selling dalam & Sangat Baik & 7 & 5 & 35 & $16 \%$ & 4,02 \\
\hline
\end{tabular}




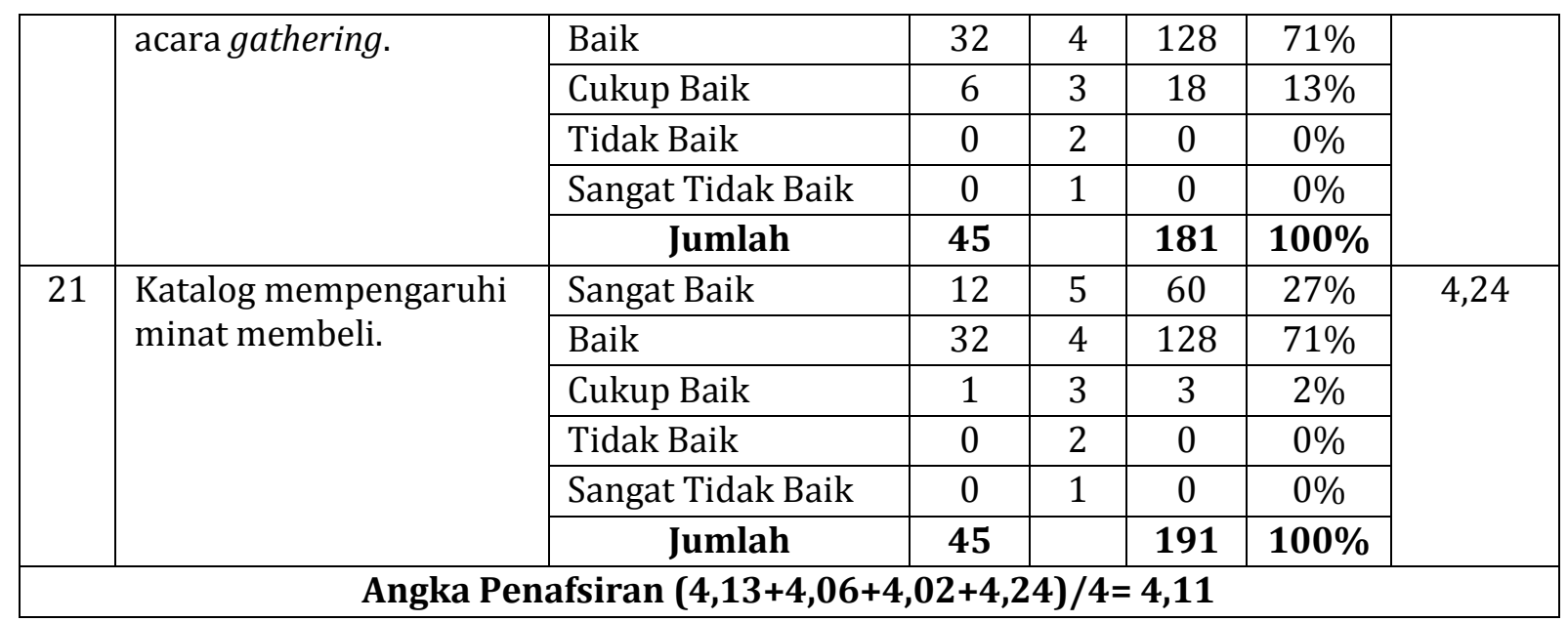

Sumber : Pengolahan data primer, 2014.

Berdasarkan Tabel 2. Diatas dapat dijelaskan bahwa hasil penelitian menunjukan bahwa sebagian distributor menyatakan baik (49\%) dan sangat baik (47\%) terhadap kualitas produk yang artinya kualitas produk oriflame memanfaatkan bahan alami dari tumbuhan dengan angka penafsiran sebesar 4,28 termasuk dalam kategori sangat baik, dan hanya sebagian kecil distributor yang menyatakan cukup baik (4\%). Demikian hal nya tanggapan distributor terhadap produk yang aman dan sehat bagi semua jenis kulit, sebagian besar distributor menyatakan baik (56\%) dan sangat baik (40\%) dengan angka penafsiran sebesar 4,35 yang termasuk dalam kategori sangat baik, dan hanya sebagian kecil distributor yang menyatakan cukup baik (4\%). Dan tanggapan distributor terhadap produk dapat digunakan oleh kaum muslim bahwa sebagian distributor menyatakan sangat baik (51\%) dan baik (47\%) dengan angka penafsiran 4,48 yang termasuk dalam kategori sangat baik.

Demikian hal nya tanggapan distributor mengenai produk tanpa bahan kimia, sebagian besar distributor menyatakan baik $(65 \%)$ dan baik (31\%) dengan angka penafsiran 4,27 yang termasuk dalam kategori sangat baik, dan hanya sebagian kecil distributor yang menyatakan cukup baik (4\%). Selanjutnya dapat dijelaskan bahwa angka penafsiran ratarata untuk dimensi kualitas produk oriflame adalah sebesar 4,34 yang termasuk dalam kategori sangat baik, hal ini mengandung pengertian bahwa pada umumnya distributor menyatakan adanya kesesuaian kualitas pelayanan produk oriflame dengan yang dirasakan distributor.

Selanjutnya, hasil penelitian menunjukan bahwa sebagian besar distributor menyatakan baik (58\%) dan sangat baik (38\%) terhadap kegemaran aroma bunga dan buah dengan angka penafsiran 4,33 yang termasuk dalam kategori sangat baik, dan hanya sebagian kecil menyatakan cukup baik (4\%). Demikian hal nya dengan memanfaatkan telur dan madu dari hewani bahwa sebagian besar distributor menyatakan baik (58\%) dan sangat baik (38\%) dengan angka penafsiran 4,33 yang termasuk dalam kategori sangat baik, dan hanya sedikit yang menyatakan cukup baik (4\%). Selanjutnya, hasil penelitian menunjukan bahwa sebagian besar distributor terhadap memenuhi kebutuhan konsumen dari kecantikan sampai kesehatan menyatakan baik (62\%) dan sangat baik 38\%) dengan angka penafsiran 4,37 yang termasuk dalam kategori sangat baik. Dengan angka penafsiran bahwa angka penafsiran rata-rata dimensi cirri produk oriflame sebesar 4,34 yang termasuk dalam kategori sangat baik, hal ini mengandung pengertian bahwa pada umumnya distributor menyatakan sangat baik terhadap ciri produk oriflame .

Hasil penelitian menunjukan bahwa sebagian besar distributor menyatakan baik (49\%) dan sangat baik (42\%) terhadap menggunakan bahan alami sesuai kebijakan lingkungn dengan angka penafsiran 4,33 yang termasuk dalam kategori sangat baik, dan hanya sedikit yang menyatakan cukup baik (9\%). Demikian hal nya dengan kemasan dapat 
didaur ulang dan meminimalisir limbah pabrik, distributor sebagian besar menyatakan baik (65\%), sangat baik (20\%), dan cukup baik (15\%) dengan angka penafsiran 4,04 yang termasuk kategori baik. Selanjutnya, hasil penelitian menunjukan bahwa oriflame diformulasikan dan diproduksi sesuai pedoman etika menyatakan baik (67\%), sangat baik (20\%), dan cukup baik (13\%) dengan angkak penafsiran 4,07 dengan kategori baik. Ratarata dimensi desain produk oriflame adalah sebesar 4,15 yang termasuk kategori baik, hal ini mengandung pengertian distributor pada umumnya menyatakan baik terhadap desain produk oriflame.

Selanjutnya, hasil penelitian menunjukan bahwa sebagaian besar distributor menyatakan baik (73\%) dan cukup baik (20\%) terhadap harga dapat bersaing lebih murah dengan angka penafsiran 3,87 yang termasuk kategori baik, dan hanya sedikit yang menyatakan sangat baik (7\%). Demikian hal nya dengan menjangkau kantong pelajar, sebagian besar distributor menyatakan baik (67\%), sangat baik (13\%), dan cukup baik (13\%) dengan angka penafsiran 3,82 yang termasuk kategori baik, dengan sedikit yang menyatakan tidak baik (2\%). Demikian hal nya dengan diskon, sebagian besar distributor menyatakan baik (69\%) dan baik (22\%) dengan angka penafsiran 4,13 yang termasuk dalam kategori sangat baik, dan hanyah sedikit yang menyatakan cukup baik (9\%). Selanjutnya hasil penelitian menunjukan bahwa sebagian besar distirutor menyatakan baik (60\%), sangat baik (16\%), tidak baik (13\%), cukup baik (9\%), dan sangat tidak baik (2\%) terhadap harga yang murah mempengaruhi kualitas produk dengan angka penafsiran 3,73 yang termasuk dalam kategori baik. Selanjutnya dapat dijelaskan bahwa angka penafsiran rata-rata dimensi untuk penetapan harga adalah sebesar 3,89 yang termasuk dalam kategori baik, hal ini mengandung pengertian bahwa distributor baik pada penetapan harga produk oriflame.

Hasil penelitian menunjukan bahwa sebagian distributor menyatakan baik (47\%) dan sangat baik (38\%) pada SPO mempermudak melakukan order dengan angka penafsiran 4,22 dengan kategori sangat baik, dan cukup baik (15\%). Demikian hal nya dengan gedung mencukup training, sebagian besar distributor menyatakan baik (62\%), dan sangat baik $(29 \%)$ dengan nagka penafsiran 4,20 yang termasuk dalam kategori baik, dan hanya sedikit yang menyatakan cukup baik (9\%). Selanjutnya, sebagaian besar distributor menyatakan baik (58\%) dan sangat baik (35\%) pada kenyamanan SPO dengan angka penafsiran 4,29 termasuk kategori sangat baik, dengan hanya sedikit yang menyatakan cukup baik (7\%). Selanjutnya dapat dijelaskan bahwa angka penafsiran rata-rata untuk dimensi gedung/ruangan SPO adalah sebesar 4,34 termasuk dalam kategori sangat baik, hal ini mengandung arti ruangan/gedung SPO sangat baik terhadap distributor.

Selanjutnya, hasil penelitian menunjukan bahwa sebagian distributor menyatakan baik (60\%), sangat baik (27\%) dan cukup baik (13\%) terhadap open table di bazaar dengan angka penafsiran 4,13 dengan kategori baik. Demikian hal nya dengan gencar melakukan promosi, sebagian distributor menyatakan baik (75\%) dan sangat baik (16\%) dengan angka penafsiran 4,06 termasuk kategori baik, dengan hanya sedikit yang menyatakan cukup baik (95\%). Selanjutnya menunjukan bahwa sebagian besar distributor menyatakan baik (71\%) dan sangat baik (16\%) terhadap acara gathering dengan angka penafsiran sebesar 4,02 termasuk kategori baik, dan hanya sedikit yang menyatakan cukup baik (13\%). Dan hasil penelitian menunjukan bahwa katalog mempengaruhi minat pembeli, sebagian besar distributor menyatakan baik (71\%) dan sangat baik (27\%) dengan angka penafsiran 4,24 termasuk kategori sangat baik, dengan hanya sedikit yang menyatakan cukup baik (2\%). Dengan demikian, bahwa angka penafssiran rata-rata dimensi promosi oriflame adalah sebesar 4,11 yang termasuk baik, hal ini mengandung arti bahwa promosi oriflame baik untuk distributor.

Dengan demikian, variabel strategi komunikasi pemasaran oriflame dengan indikator kualitas produk, ciri produk, desain produk, penetapan harga, gedung/ruangan SPO, dan promosi dapat direkapitulasi dengan tabel sebagai berikut : 
Tabel 3. Rekapitulasi Angka Penafsiran Indikator Strategi Komunikasi Pemasaran

\begin{tabular}{|c|l|c|c|}
\hline No & \multicolumn{1}{|c|}{ Indikator } & Kriteria Penafsiran & Interval Skor \\
\hline 1 & Kualitas Produk & 4,34 & Sangat Baik \\
\hline 2 & Ciri Produk & 4,34 & Sangat Baik \\
\hline 3 & Desain Produk & 4,15 & Baik \\
\hline 4 & Penetapan Harga & 3,89 & Baik \\
\hline 5 & Gedung/Ruangan SPO & 4,34 & Sangat Baik \\
\hline 6 & Promosi & 4,11 & Baik \\
\hline \multicolumn{2}{|c|}{ Rata-rata } & $\mathbf{2 5 , 1 7 / 6 = 4 , 1 9}$ & Baik \\
\hline
\end{tabular}

Sumber : Pengolahan data primer, 2014.

\section{Kepercayaan Distributor}

Kepercayaan distributor SPO 1088 Taman Topi Square yang dimaksud adalah bagaimana kepercayaan distributor dari strategi komunikasi pemasaran multi level marketing oriflame. Adapun indikator dari kepercayaan distributor yaitu luar biasa, menghasilkan uang, dan bersenang-senang. Diukur dengan menggunakan "Skala Likert" yaitu datanya masih skala ordinal/data primer. Untuk mengukur hasil penelitian tersebut dapat dilihat dari tabel sebagai berikut:

Tabel 4. Distribusi Distributor Oriflame Berdasarkan Kepercayaan

\begin{tabular}{|c|c|c|c|c|c|c|c|}
\hline No & $\begin{array}{l}\text { Kepercayaan } \\
\text { Distirbutor Oriflame }\end{array}$ & $\begin{array}{l}\text { Tanggapan } \\
\text { Distributor }\end{array}$ & f & $(x)$ & $f(x)$ & $\%$ & $\Sigma \mathrm{f}(\mathrm{x}) / \mathrm{n}$ \\
\hline \multicolumn{8}{|c|}{ Luar Biasa } \\
\hline \multirow[t]{6}{*}{1} & \multirow{6}{*}{$\begin{array}{l}\text { Mempertemukan } \\
\text { dengan banyak teman } \\
\text { baru. }\end{array}$} & Sangat Puas & 12 & 5 & 60 & $27 \%$ & \multirow[t]{6}{*}{4,13} \\
\hline & & Puas & 27 & 4 & 108 & $60 \%$ & \\
\hline & & Cukup Puas & 6 & 3 & 18 & $13 \%$ & \\
\hline & & Tidak Puas & 0 & 2 & 0 & $0 \%$ & \\
\hline & & Sangat Tidak Puas & 0 & 1 & 0 & $0 \%$ & \\
\hline & & Jumlah & 45 & & 186 & $100 \%$ & \\
\hline \multirow[t]{6}{*}{2} & \multirow{6}{*}{$\begin{array}{l}\text { Impian akan menjadi } \\
\text { kenyataan. }\end{array}$} & Sangat Puas & 16 & 5 & 80 & $36 \%$ & \multirow[t]{6}{*}{$4,27 \%$} \\
\hline & & Puas & 25 & 4 & 100 & $57 \%$ & \\
\hline & & Cukup Puas & 4 & 3 & 12 & $27 \%$ & \\
\hline & & Tidak Puas & 0 & 2 & 0 & $0 \%$ & \\
\hline & & Sangat Tidak Puas & 0 & 1 & 0 & $0 \%$ & \\
\hline & & Jumlah & 45 & & 192 & $100 \%$ & \\
\hline \multirow[t]{6}{*}{3} & \multirow{6}{*}{$\begin{array}{l}\text { Ilmu yang didapat dari } \\
\text { seminar. }\end{array}$} & Sangat Puas & 7 & 5 & 35 & $16 \%$ & \multirow[t]{6}{*}{$3,95 \%$} \\
\hline & & Puas & 29 & 4 & 116 & $64 \%$ & \\
\hline & & Cukup Puas & 9 & 3 & 27 & $20 \%$ & \\
\hline & & Tidak Puas & 0 & 2 & 0 & $0 \%$ & \\
\hline & & Sangat Tidak Puas & 0 & 1 & 0 & $0 \%$ & \\
\hline & & Jumlah & 45 & & 178 & $100 \%$ & \\
\hline \multirow[t]{6}{*}{4} & \multirow{6}{*}{$\begin{array}{l}\text { Meningkatkan rasa } \\
\text { saling memiliki. }\end{array}$} & Sangat Puas & 20 & 5 & 100 & $44 \%$ & \multirow[t]{6}{*}{$4,35 \%$} \\
\hline & & Puas & 21 & 4 & 84 & $47 \%$ & \\
\hline & & Cukup Puas & 4 & 3 & 12 & $9 \%$ & \\
\hline & & Tidak Puas & 0 & 2 & 0 & $0 \%$ & \\
\hline & & Sangat Tidak Puas & 0 & 1 & 0 & $0 \%$ & \\
\hline & & Jumlah & 45 & & 196 & $100 \%$ & \\
\hline \multicolumn{8}{|c|}{ Angka Penafsiran $(4,13+4,27+3,95+4,35) / 4=4,17$} \\
\hline \multicolumn{8}{|c|}{ Menghasilkan Uang } \\
\hline \multirow[t]{2}{*}{5} & \multirow{2}{*}{$\begin{array}{l}\text { Keuntungan yang } \\
\text { banyak. }\end{array}$} & Sangat Puas & 9 & 5 & 45 & $20 \%$ & \multirow[t]{2}{*}{$4,11 \%$} \\
\hline & & Puas & 32 & 4 & 128 & $71 \%$ & \\
\hline
\end{tabular}




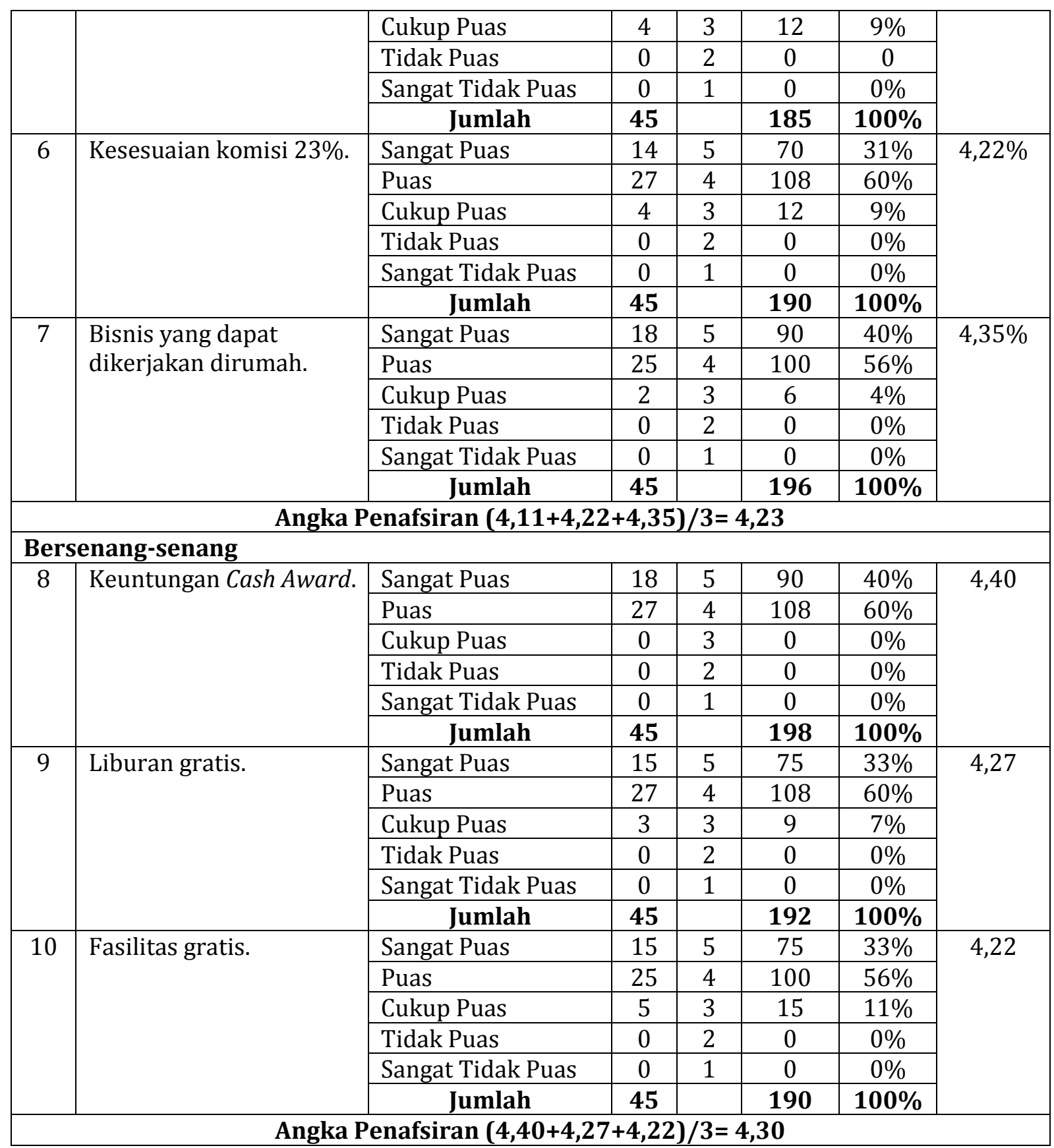

Sumber : Pengolahan data primer, 2014

Berdasarkan Tabel 4 dapat dijelaskan bahwa hasil penelitian menunjukan bahwa sebagian besar distributor merasa puas (60\%) dan sangat puas $(27 \%)$ terhadap oriflame yang dapat memperluas jaringan dalam hal mempertemukan teman baru dengan angka penafsiran 4,13 termasuk kategori baik, dan hanya sedikit yang menyatakan cukup puas (13\%). Demikian hal nya dengan tanggapan distributor terhadap impian yang akan menjadi kenyataan, sebagian besar distributor menyatakan puas (57\%), sangat puas (36\%) dan cukup puas (27\%) dengan angka penafsiran 4,27 termasuk kategori sangat baik. Selanjutnya, tanggapan distributor mengenai ilmu yang didapat dari seminar, sebagian distributor menyatakan puas (64\%), cukup puas (20\%) dan sangat puas (16\%) dengan angka penafsiran sebesar 3,95 yang termasuk kategori baik. Demikian hal nya dengan tanggapan distributor terhadap meningkatkan rasa saling memiliki, sebagian besar distributor menyatakan puas (47\%) dan sangat puas (44\%) dengan angka penafsiran 4,35 termasuk kategori sangat baik, dan hanya sebagian kecil yang menyatakan cukup puas (9\%). 
Hasil penelitian menunjukan bahwa sebagian besar distributor menyatakan puas (71\%) dan sangat puas $(20 \%)$ terhadap keuntungan yang banyak dengan angka penafsiran 4,11 yang termasuk kategori baik, dan hanya sebagian kecil yang menyatakan cukup puas (9\%). Selanjutnya, sebagian besar distributor menyatakan puas $(60 \%)$ dan sangat puas (31\%) terhadap kesesuaian komisi dengan angka penafsiran 4,22 termasuk kategori sangat baik, dan hanya sedikit yang menyatakan cukup puas (9\%). Demikian hal nya dengan bisnis yang dapat dikerjakan dirumah, sebagian besar distributor menyatakan puas (56\%) dan sangat puas (40\%) dengan angka penafsiran 4,35 termasuk kategori sangat baik, dan hanya sebagian kecil yang menyatakan cukup puas (4\%).
Hasil penelitian menunjukan bahwa sebagian besar distributor menyatakan puas $(60 \%)$ dan sangat puas (40\%) terhadap keuntungan cash award dengan angka penafsiran 4,40 termasuk kategori sangat baik. Demikian hal nya dengan liburan gratis, sebagian distributor menyatakan puas $(60 \%)$ dan sangat puas (33\%) dengan angka penafsiran 4,27 termasuk kategori sangat baik, dengan hanya sebagian kecil yang menyatakan cukup puas (7\%). Selanjutnya, bahwa sebagian besar distributor menyatakan puas (56\%) dan sangat puas (33\%) terhadap fasilitas gratis dengan angka penafsiran 4,22 termasuk kategori sangat baik, dengan sebagian kecil yang menyatakan cukup puas (11\%).

Tabel 5. Rekapitulasi Angka Penafsiran Kepercayaan Distributor

\begin{tabular}{|l|l|c|c|}
\hline No & Indikator & Kriteria Penafsiran & Interval Skor \\
\hline 1 & Luar Biasa & 4,17 & Baik \\
\hline 2 & Mengahasilkan Uang & 4,23 & Sangat Baik \\
\hline 3 & Bersenang-senang & 4,30 & Sangat Baik \\
\hline \multicolumn{2}{|c|}{ Rata-rata } & $\mathbf{1 2 , 7 / 3 = 4 , 2 3}$ & Sangat Baik \\
\hline
\end{tabular}

Sumber : Pengolahan data primer, 2014

\section{Uji Hipotesis}

Uji hipotesis untuk mengetahui pengaruh strategi komunikasi pemasaran terhadap kepercayaan distributor secara menyeluruh berdasarkan uji Rank Spearman dapat dilihat pada tabel berikut:

Tabel 6. Hasil Uji Hipotesis

\begin{tabular}{lllrr}
\hline \multicolumn{5}{c}{ Correlations } \\
\hline Spear & $\mathrm{X}$ & X & $\mathrm{Y}$ \\
man's & & Correlation & 1.000 & $.513^{* *}$ \\
rho & Coefficient & & .000 \\
& & Sig. (2-tailed) & 45 & 45 \\
& & $\mathrm{~N}$ & $.513^{* *}$ & 1.000 \\
& $\mathrm{Y}$ & & \\
& & Correlation & .000 &. \\
& Coefficient & 45 & 45 \\
\hline
\end{tabular}

**. Correlation is significant at the 0.01 level (2-tailed).

Berdasarkan Tabel 6, analisis koefisien korelasi spearman's rho antara strategi komunikasi pemasaran terhadap kepercayaan distributor di dapat koefisien sebesar 0,513**. Maka dapat disimpulkan bahwa strategi komunikasi pemasaran terhadap kepercayaan distributor adalah sedang. 
Untuk mengetahui diterima atau ditolaknya hipotesisi maka dilakukan pengujian signifikan koefisien korelasi dengan rumus t-tes.

Dari hasil perhitungan diperoleh nilai $t_{\text {hitung }}$ hasil penelitian sebesar 4,567. Kemudian nilai $t_{\text {hitung }}$ dibandingkan dengan $t_{\text {tabel }}$ distribusi $t$ dengan taraf signifikan (a) $=0,05$ dengan derajat kebebasan $(\mathrm{df})=\mathrm{n}-2$. Maka nilai $\mathrm{t}_{\text {tabel }}$ adalah 1,973. Hal tersebut menunjukan bahwa ternyata nilai $t_{\text {hitung }}>t_{\text {tabel }}$. Dengan demikian terdapat pengaruh yang signifikan pada strategi komunikasi pemasaran multi level marketing oriflame terhadap kepercayaan distributor sebagai mitra usaha. Hal tersebut mengidentifikasikan bahwa hipotesis yang diajukan diterima dan diterima kebenarannya, sehingga Ho ditolak Ha diterima. Artinya, terdapat pengaruh yang signifikan pada strategi komunikasi pemasaran multi level marketing oriflame terhadap kepercayaan distributor sebagai mitra usaha.

Setelah mengetahui tingkat pengaruh dan signifikansi, kemudian untuk mengetahui seberapa besar pengaruh strategi komunikasi pemasaran multi level marketing terhadap kepercayaan distributor sebagai mitra usaha, dihitung seberapa besar angka koefisien determinasinya yang menunjukan besarnya kontribusi pengaruh strategi komunikasi pemasaran terhadap kepercayaan distributor untuk menghitung angka koefisien determinasi $(\mathrm{kd})$ digunakan rumus sebagai berikut $: \mathrm{Kd}=\mathrm{r}^{2}$ $\mathrm{x} 100 \%$

$\mathrm{Kd}=(0,513)^{2} \times 100 \%$

$\mathrm{Kd}=26,32 \%$

Untuk mengetahui kontribusi faktor lain digunakan rumus :

$\mathrm{E}=1-\mathrm{Kd} \times 100 \%$

$E=1-0,2632 \times 100 \%$

$\mathrm{E}=0,7368 \times 100 \%$

Jadi, $E=73,68 \%$

Dengan demikian dapat disimpulkan bahwa tingkat kontribusi korelasi dalam penelitian ini sebesar 26,32\% dan kontribusi faktor lainnya (epsilon) adalah 73,68\%. Jadi, tingkat pengaruh strategi komunikasi pemasaran terhadap kepercayaan distributor sebesar 26,32\% dan tingkat pengaruh dari faktor lain sebesar $73,68 \%$.

\section{KESIMPULAN DAN SARAN}

\section{Kesimpulan}

Berdasarkan hasil penelitian pada bab sebelumnya, maka dapat disimpulkan sebagai berikut :

1. Strategi komunikasi pemasaran multilevel marketing oriflame Taman Topi Square Bogor dilihat dari kualitas produk, ciri produk, dan fasilitas gedung/ruangan SPO dikatakan sangat baik, sedangkan desain produk, penetapan harga, dan bauran promosi dikatakan baik. Sehingga strategi komunikasi pemasaran yang dilakukan oriflame tercapai dengan baik sesuai dengan sasaran dan tujuan yang ditentukan dalam penyampaian informasi produknya, dengan angka penafsiran 4,19.

2. Kepercayaan yang meyakinkan distributor sebagai mitra usaha pada oriflame dilihat dari hal luar biasa adalah baik yang dapat mempertemukan banyak teman baru dari berbagai latar belakang, sedangkan kepercayaan yang meyakinkan distributor dilihat dari hal menghasilkan uang dan bersenang-senang adalah sangat baik sehingga adanya kesesuaian antara yang dirasakan dan diharapkan distributor. Sehingga kepercayaan distributor dikatakan sangat baik dengan angka penafsiran 4,23.

3. Strategi komunikasi pemasaran multi level marketing oriflame berpengaruh terhadap kepercayaan distributor sebagai mitra usaha pada tingkat pengaruh sedang $(26,32 \%)$. Sehingga terdapat pengaruh antara strategi komunikasi pemasaran terhadap kepercayaan distributor.

\section{Saran}

Berdasarkan hasil penelitian, maka dapat disarankan sebagai berikut :

1. Sebaiknya, Oriflame lebih meningkatkan desain produk untuk dapat lebih menarik minat distributor dan penetapan harga lebih menjangkau seperti dapat menjangkau kantong pelajar dan dengan harga yang murah pun akan mendapatkan kualitas produk yang baik.

2. Oriflame juga diharapkan lebih meningkatkan strategi promosi, hal ini agar lebih mempengaruhi dan meningkatkan kepercayaan distributor. Sehingga distributor selalu merasa puas 
dan yakin untuk tetap bergabung bersama oriflame.

\section{DAFTAR PUSTAKA}

Ardianto E. 2010. Metode Penelitian Untuk Public Relations Kuantitatif dan Kualitatif : Bandung (ID): Simbiosa.

Bloom, PN dan Louise NB. 2006. Strategi Pemasaran Produk Edisi Terjemahan. Jakarta (ID): Prestasi Pustaka.

Dantes N. 2012. Metode Penelitian. Yogyakarta (ID): Andi.

Effendy O. 1986. Dimensi-Dimensi Komunikasi. Bandung (ID) : Rosda Karya.

Hermawan A. 2012. Komunikasi Pemasaran. Jakarta (ID): Erlangga.

Iriantara Y. 2004. Community Relations. Bandung (ID) : Rosdakarya.

Jenu WT. 2013. Stop Promotion Start Communication. Jakarta (ID) : Elex Media Computindo.

Kennedy JE, RD Soemanagara. 2006. Marketing Communication Taktik dan Strategi. Jakarta (ID) : PT. Buana Ilmu Populer (kelompok Gramedia).

Kotler dan Amstrong. 2003. Dasar-Dasar Pemasaran, Edisi Ke Sembilan. Jakarta (ID) : PT. Indeks Kelompok Gramedia.

Kotler P dan Keller KL.2008. Manajemen Pemasaran, Edisi Kedua Belas. Jakarta (ID): PT. Indeks.

Littlejhon SW. 2009. Teori Komunikasi. Jakarta (ID) : Salemba Humanika

Mahmud M. 2010. Komunikasi Pemasaran Modern. Yogyakarta (ID) : Cakra Ilmu

Mulyana D. 2008. Ilmu Komunikasi, Bandung (ID) : Rosdakarya.

Novirina SI. 2012. Analisis Pengaruh Citra Merk, Kualitas Produk, Dan Harga Terhadap Minat Beli Produk Oriflame.[SKRIPSI]. Semarang (ID): Fakultas Ekonomika dan Bisnis Universitas Diponegoro.

Prisgunanto I. 2006. Komunikasi Pemasaran Startegi \& Taktik. Bogor (ID) : Ghalia Indonesia

Ramadhani P. 2013. Pengaruh Kualitas Pelayanan Informasi Jasa dan Produk Bank X Bagian Custemer Services Terhadap Kepuasan Nasabah. [SKRIPDI]. Bogor (ID) : FISIP Universitas Djuanda Bogor.
Rahmadhani A. 2011. Strategi Komunikasi Perusahaan Oriflame Dalam Merekrut Customer Di Kota Makassar. Makassar (ID) : Komunikasi FISIP Universitas Hasanudin Makassar.

Ruslan R. 2010. Metode Penelitian Public Relation \& Komunikasi. Jakarta (ID) : Rajawali Pers.

Tjiptono F. 2008. Strategi Bisnis Pemasaran. Yogyakarta (ID) : Andi.

Uyanto S. 2006. Pedoman Analisis Data Dengan SPSS. Yogyakarta (ID) : Graha Ilmu.

Winardi. 1989. Strategi Pemasaran: Marketing Startegy. Bandung (ID) : Mandar Maju. 